DOI: $10.21767 / 2172-0479.100021$

\title{
Review of Medicinal Plants for Anti-Obesity Activity
}

\begin{abstract}
Obesity is a complex health issue to address, it is a serious and chronic disease that can have a negative effect on many systems in your body. Overweight and obesity may increase the risk of many health problems, including diabetes, heart disease, osteoarthritis and certain cancers. Obesity is increasing at an alarming rate throughout the world. Today it is estimated that there are more than $\mathbf{3 0 0}$ million obese people world-wide. Obesity is regarded as a disorder of lipid metabolism and the enzymes involved in this process could be targeted selectively for the development of antiobesity drugs. However, most of the anti-obesity drugs that were approved and marketed have now been withdrawn due to serious adverse effects. The naturopathic treatment for obesity has been explored extensively since ancient times and gaining momentum in the present scenario. Traditional medicinal plants and their active phytoconstituents have been used for the treatment of obesity and their associated secondary complications. Some active medicinal plants and their respective bioactive compounds were also tested by clinical trials and are effective in traemnet of obesity. This review focus on natural phytoextracts with their mechanism of action and their preclinical experimental model for further scientific research.
\end{abstract}

Keywords: Obesity; Antiobesity drugs; Medicinal plants

Received: August 20, 2015; Accepted: December 01, 2015; Published: December 04, 2015

\section{Introduction}

In the present scenario, obesity is the major public health problem with about 1.9 billion adults (18 years and older) worldwide are overweight and about 600 million of them are clinically obese [1]. Obesity is characterized by increase in adipose cell size which is determined by amount of fat accumulated in the cytoplasm of adipocytes [2]. This change in the metabolism in the adipocytes is regulated by various enzymes such as fatty acid synthase, lipoprotein lipase and adipocyte fatty acid-binding protein [3].

Obesity results from an imbalance between energy intake and expenditure. It is caused by altered lipid metabolic processes including lipogenesis and lipolysis [4]. Lipogenesis is the process that stores free fatty acids in the form of triglyceride (TG) [5]; similarly, lipolysis is the process whereby the TG stored is metabolized to free fatty acids and glycerol [6]. Obesity accompanied by hyperlipidemia which is indicated by abnormally high concentration of lipids in blood [7]. The adipose tissue, an endocrine organ, has a major role in the regulation of metabolism and homeostasis, through the secretion of several biologically active adipokines [8]. During adipose tissue development, three

\section{Satyajit Patra', S Nithya ${ }^{2}$, B Srinithya ${ }^{2}$ and Meenakshi SM²}

\section{Division of Biochemistry and Genetics American International Medical University, Saint Lucia, WI, USA

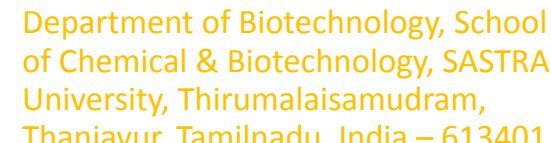 \\ Thanjavur, Tamilnadu, India - 613401}

Corresponding author: Dr. Satyajit Patra

\section{झ dr.patra@aimu-edu.us}

Division of Biochemistry and Genetics, American International Medical University, Saint Lucia, WI, USA.

Tel: 1-758-488-0322

Citation: Patra S, Nithya S, Srinithya B, et al. Review of Medicinal Plants for Anti-Obesity Activity. Transl Biomed. 2015, 6:3. 
reduces fat absorption through inhibition of pancreatic lipase and the second is subutramine which is an anorectic or appetite suppressant. Both drugs have adverse effects including increased blood pressure, headache, drymouth, insomnia, and constipation $[15,16]$. In 1990 Fenfluramine and Dexfenfluramine were withdrawn from the market because of heart valve damage [17]. The US FDA in 1997 approved subutramine drug as a treatment for obesity. But later in October 2010 the drug was withdrawn from the market due to increased cardiovascular events and strokes $[18,19]$. In February 2011 the US FDA rejected approval of contrive which is a combination of bupropion/naltrexone due to concerns over potential cardiovascular risks [20]. Certain drugs have potential for abuse such as phentermine and diethylpropion and hence are approved for short term use [21].

At present, because of high cost and potentially hazardous side effects, the need for natural products against obesity is under exploration which may be an alternative strategy for developing effective, safe antiobesity drugs [22]. In 2000, Moro and Basile reported the use of certain well known medicinal plants that had claimed to be useful in treating obesity. The antiobesity effects of natural products from more diverse sources [23]. The aim of the present review was to update data on potential antiobesity herbal plants.

\section{Methods}

Databases used for this study to search include PubMed, Scopus, Google Scholar, Web of Science, and IranMedex with information reported between September 2, 2006 to September 22,2014 . Search of literatures was focused on human or animals investigating the benefits and harms of herbal medicines to treat obesity. The search terms were "obesity" and ("herbal medicine" or "plant", "plant medicinal" or "medicine traditional") without narrowing or limiting search items. Publications with abstract from the mentioned databases were used to prepare this review. The main outcome measures were defined as body weight, body fat, including fat mass/fat weight or fat percentage/visceral adipose tissue weight, waist or hip circumference, triceps thickness and appetite, and the amount of food/energy intake. Abstracts of publications on plants used to evaluate the activity on human, animals, cell lines studies with the main outcome as mentioned above were included. In vitro studies, review articles and letters to the editor were excluded. Two reviewers reviewed the articles for abstracts and title. Due to our inclusion and exclusion criteria, the duplicate articles were eliminated. The review includes active components and mechanism of action against obesity in animals and presented in Table 1 . Some of the plants are tested for their activity against obesity in cell lines listed in Table $\mathbf{2}$ and plants that were tested on human volunteers or clinical trails are listed in Table 3. In some instances scientist have evaluated the anti-obesity activity in isolated cell organelles, isolated cellular enzymes specifically pancreatic lipase are listed in Tables $\mathbf{3}$ and $\mathbf{4}$ respectively. Table 4 present the plant which was studied for its activity against obesity in an in silico model.

\section{Discussion}

In this review, we have report the antiobesity effects of different herbal plants or compounds containing minerals or chemical extracts of plants. Plants having reported antiobesity effects are listed in Table 1 with information about their active components and their effects. From the review it was suggested that, plant showing anti-obesity potential mainly belongs to the family Leguminoseae, Lamiaceae, Liliaceae, Cucurbitaceae, Asteraceae, Moraceae, Rosaceae and Araliaceae. Majority of the studies indicates decrease in body weight or body weight gain in animals and humans with or without changes in body fat indicating antiobesity effects. The antiobesity effects such as body weight reduction, decrease in the levels of triglycerides, total cholesterol, and low density lipoprotein cholesterol with simultaneous increase in high density lipoprotein cholesterol was observed in the animals treated with the plants $[1,15,29,31,39,54,60,78,79,83$ $, 85,98,100,101,133,145,152,165,190,196,201]$. In one study [41], it has been reported that a compound chakasaponin II, suppressed mRNA levels of neuropeptide $Y$ (NPY) and enhanced the release of serotonin (5-HT) that suppressed the appetite signals in the hypothalamus of the mice. Clinical trials were conducted on humans for various plant extracts $[45,49,135]$ which showed a significant decrease in body weight and body fat reduction. There

Table 1. Anti-obesity effect of natural occurring plants with mechanism of action studied on animal models

\begin{tabular}{|c|c|c|c|c|c|}
\hline & Plant name & Part(s) & Mechanism & Experimental model & Reference \\
\hline 1 & $\begin{array}{l}\text { Achyranthes aspera } \\
\text { Linn } \\
\text { (Amaranthaceae) }\end{array}$ & Seed & $\begin{array}{l}\text { The plant lowers total cholesterol, total triglyceride, and } \\
\text { LDL-cholesterol, and increases HDL cholesterol level. }\end{array}$ & $\begin{array}{l}\text { High-fat-fed male Swiss } \\
\text { albino mice }\end{array}$ & [24] \\
\hline 2 & $\begin{array}{l}\text { Acorus calamus Linn } \\
\text { (Araceae) }\end{array}$ & $\begin{array}{l}\text { Rhizome, roots } \\
\text { and leaves }\end{array}$ & $\begin{array}{l}\text { Ethyl acetate extarct of } A \text {. calamus inhibits } \alpha \text {-glucosidase } \\
\text { activity. }\end{array}$ & Glucose challenged mice. & {$[25]$} \\
\hline 3 & $\begin{array}{l}\text { Achyranthes } \\
\text { bidentata Blume } \\
\text { (Amaranthaceae) }\end{array}$ & Root & $\begin{array}{l}\text { The drug affects on differentiation of adipocyte and } \\
\text { decrease of phospho-Akt expression. }\end{array}$ & $\begin{array}{l}\text { Male Sprague-Dawley fed } \\
\text { with a high-fat diet }\end{array}$ & {$[26]$} \\
\hline 4 & $\begin{array}{l}\text { Actinidia polygama } \\
\text { Max } \\
\text { (Actinidiaceae) }\end{array}$ & Fruits & $\begin{array}{l}\text { Serum levels of aspartate decreased in the mice treated } \\
\text { with the extract without changes in serum levels of } \\
\text { alanine transaminase blood urea nitrogen and creatinine. }\end{array}$ & $\begin{array}{l}\text { Mice with high-fat diet } \\
\text { induced obesity }\end{array}$ & {$[27]$} \\
\hline 5 & $\begin{array}{l}\text { Adenophora triphylla } \\
\text { Hara } \\
\text { (Campanulaceae) }\end{array}$ & Root & $\begin{array}{l}\text { Anti-obesity effect of } A \text {. triphylla is mediated by } \\
\text { increasing adipocytes adiponectin and activating pathway } \\
\text { like AMPK, and PPAR- } \alpha \text {, and decreasing adipokines TNF- } \alpha \text {, } \\
\text { GPDH, and PPAR- } \alpha \text {. It also actively expresses low-density } \\
\text { lipoprotein [LDL] receptor and cholestorl } 7 \alpha \text { - hydroxylase } \\
\text { (CYA7A1) and inhibits expression of } 3 \text { hydroxy- } 3 \text { methyl } \\
\text { glutaryl - CoA (HMG-CoA) reductase. }\end{array}$ & $\begin{array}{l}\text { High fat diet (HFD)- } \\
\text { C57B2/6 mice }\end{array}$ & {$[28,29]$} \\
\hline
\end{tabular}


Aegle marmelos Linn Leaves (Rutaceae)

7 Allium cepa Linn Peel (Amaryllidaceae)

Allium fistulosum Linn Root (Liliaceae)

9
Allium nigrum Linn
Bulb

(Amaryllidaceae)

10 Allium sativum Linn (Amaryllidaceae)

Stem, Bulb and Roots

Alpinia galanga Linn Rhizome

(Zingiberaceae)

Alpinia officinarum Root

Hance (Zingiberaceae)

Angelica gigas Roots

Nakai

Roots

(Apiaceae)

14

Argyreia nervosa

Root

(Convolvulaceae)

15 Artemisia iwayomogi Whole Plant (Compositae)

Atractylodes lancea Rhizome

(Thunb.) DC

(Compositae)

17 Aster pseudoglehni Leaves

Lim, Hyun \& Shin

(Asteraceae)

18

Bauhinia variegata

Linn

(Leguminosae)

Bergenia crassifolia Leaves

(L.) Fritsch

(Saxifragaceae)

Stem and root barks
The active chemical constituents of $A$. marmelos for antiadipogenic activity are halfordinol, ethyl ether aegeline and esculetin were responsible for the decrease in adipocyte accumulation. Active compounds umbelliferone and esculetin depletes lipid content in the adipocytes and by decreasing the hyperlipidemia.

The mRNA levels of activating protein (AP2) is downregulated by $A$.cepa and those of carnitine palmitoyl transferase-1 $\alpha$ (CPT-1 $\alpha)$ and fatty acid binding protein 4 (FABP4) are up-regulated. It is also proposed that $A$. cepa increases level of PPAR- $\gamma 2$ mRNA (mesenteric fats) and IL-6 mRNA levels (perirenal and mesenteric fats).

Significant reduction in body weight and adipose tissue weight as well as adipocyte size. Genes involved in lipogenesis are down-regulated by $A$. fistulosum.

Extract of $A$. nigrum upregulates AMPK, FOXO1, Sirt1, ATGL, HSL, perilipin, ACO, CPT-1, and UCP1 in the adipose mice tissues, whereas it downregulates CD36.

It increases antioxidant enzymes and suppresses glutathione depletion and lipid peroxidation in hepatic tissue. Oil isolated from $A$. sativum down regulates sterol regulatory element binding protein-1c, acetylcoA carboxylase, fatty acid synthase, and 3-hydroxy-3methylglutaryl-coenzyme A reductase.

Galangin, the principal compontent of $A$. galangal decreases serum lipids, liver weight, lipid peroxidation and accumulation of hepatic TGs.

High fat-fed rats, Diet-

induced obese Male

Sprague-Dawley rats

High fat diet induced obese $[30,31]$

male Sprague Drawly rat

The drug controls and improves lipid profile in animals by lowering serum Total-C, TG, and LDL-C concentrations, fat die leptin content.

Decursin, the active constituent of A.gigas improves glucose tolerance. Decursin along with the HFD significantly reduces secretion adipocytokines such as leptin, resistin, IL-6 and MCP-1.

Serum contents of leptin, total cholestrol, LDL, and triglycerides are reduced by $A$. speciosa.

It downregulates adipogenic transcription factors PPAR 2 and C/EBP $\alpha$ and their target genes CD36, aP2, and FAS. The extract decreases gene expression of proinflammatory cytokines including TNF $\alpha$, MCP1, IL-6, IFN $\alpha$, and INF $\beta$ in epididymal adipose tissue and reduces plasma levels of TNF $\alpha$ and MCP1.

It inhibits human pancreatic lipase. A new polyacetylene, High-fat diet-induced syn-(5E,11E)-3-acetoxy-4-O-(3-methylbutanoyl)-1,5,11- obesity mice tridecatriene-7,9-diyne-3,4-diol has been isolated and identified and exhibits lipase inhibitory activity.

It suppresses expression of adipogenesis-related genes including PPARY, C/EBP $\alpha$, and SREBP1c.

High fat diet induced-male C57BL/6J mice

Hypercaloric diet - induced [46]

Extract of $E$. variegata increases brain serotonin level and high-density lipoprotein with a concomitant decrease mice in total cholesterol, triglycerides and low-density lipo protein.

Galloylbergenin derivatives 3,11-Di-O-galloylbergenin and 4,11Rats with high-calorie dietdi-O-galloylbergenin are found to be present in $B$. crassifolia moderates anti-lipid accumulation activities. 


\begin{abstract}
Boehmeria nivea
Leaf
\end{abstract}

(L.) Gaudich

(Urticaceae)

21 Boerhaavia diffusa L. Root (Nyctaginaceae)

Bombax ceiba L. Stem bark (Malvaceae)

Anredera cordifolia Leaves

(Ten.) Steenis

(Basellaceae)

Brassica rapa L. Root

(Brassicaceae)

Buddleja officinalis

Maxim

(Scrophulariaceae)

26 Bursera grandiflora Roots

(Schltdl.) Engl

(Burseraceae)

27 Calanus finmarchicus Wax (Calanidae)

28 Camellia japonica L. Leaves (Theaceae)

29 Camellia oleifera Abel Fruit hull (Theaceae)

Camellia sinensis (L.) Leaves, twigs Kuntze (Theaceae) and stems, flower buds

(Pteridaceae)
The extracts reduces adipose tissue weight serum alkaline High fat/cholestrol dietaminotransferase and lactate dehydrogenase activities. Serum triglyceride, total cholesterol, LDL-cholesterol level, atherogenic index and cardiac risk factors are decreased in animals fed with leaf powder and serum $\mathrm{HDL}$-cholestrol levels are increased.

The phytoconstituents compounds sitosterol found in this plant which is structurally similar to cholesterol has been suggested to reduce cholesterol by lowering the level of LDL-cholesterol and cholesterol level decreased significantly in plasma without any side effects.

The extract and active constituent gemfibrozil reverses the effects of HFD treatment on serum parameters. This activity may be due to the inactivation of acetyl-coA carboxylase, as a result of AMPK activation that mediates thermogenesis and FAS inhibition.

The extract suppresses lipid accumulation and downregulates PPARY, CCAAT/enhancer binding protein

High-fat diet-induced $\alpha$, SREBP, and their target genes. It also increases phosphorylation of AMPK.

Lipolysis-related genes including $\beta_{3}$-adrenergic receptor, hormone-sensitive lipase, adipose triglyceride lipase, and uncoupling protein are induced in white adipocytes of animals treated with extract of $B$. campestris.

High fat diet in female

Sprague-Dawley rats

Male, Wistar albino rats obese rats

High fat diet induced mice The extract reduces body weight gain induced through adipocyte differentiation.

High-fat diet to C57BL/6 mice

B. grandiflora exerts anti-obesity activity by decreasing in the plasma-triglyceride levels.

C. finmarchicus reduces macrophage infiltration and downregulates expression of proinflammatory genes including tumor necrosis factor- $\alpha$, interleukin- 6 , and monocyte chemoattractant protein-1, whereas upregulates adiponectin expression.

C. japonica control insulin which is a modulator of lipid synthesis via sterol regulatory element binding protein1c (SREBP-1c), decreased levels of insulin affects hepatic triglyceride synthesis.

Serum levels of total cholesterol and triacylglycerols are decreased but high-density lipoprotein cholesterol increased.Activity of fatty acid in animal liver is lowered by.

C. sinesis attenuates the gene expression of (SREBP-1C), fatty acid synthase and CCAAT/enhancer binding protein $\alpha$. Extract found to reduce sICAM-1 release followed by nonpharmacological HGTE supplementation in $\mathrm{db} / \mathrm{db}$ mice causing no adiponectin-inducing or antiadipogenic effects, reduced sICAM-1 release. Chakasaponin II from flower bud, suppresses mRNA levels of neuropeptide $Y(N P Y)$. The mRNA levels of adipogenic genes such as PPAR- $\gamma, C / E B P-\alpha$, SREBP-1c, adipocyte fatty acid-binding protein, lipoprotein lipase and fatty acid synthase are decreased in $C$. Sinensis treated animals.

Extract of $C$. albomarginata lowers plasma triglyceride activity as well as reduces weight of adipose tissue.
High fat diet induced Sprague-Dawley rats

Male ICR mice were fed a [57] HFD

Albino rats fed on high-fat diet, diet-induced obesity fat induced- C57BL/6JLepob/ob mice, high fat diet- induced C57BL/6J mice

High fat diet induced obese [65] male Sprague Dawleyrats in Female ddY mice, high 
Chenopodium quinoa Seeds

Willd

(Amaranthaceae)

Gray

(Compositae)

Citrus reticulata Peel

Blanco

(Rutaceae)

35 Citrus sunki (Hayata) Peel

Yu.Tanaka

(Rutaceae)

36 Clerodendrum Roots

phlomidis L. $\mathrm{f}$.

(Lamiaceae)

37 Coccinia grandis (L.) Fruit Voigt

(Cucurbitaceae)

38 Codonopsis lanceolata Roots (Siebold \& Zucc.)

Benth. \& Hook.f. ex

Trautv

(Campanulaceae)

39 Coffea arabica L. Seed

(Rubiaceae)

40 Coleus forskohlii Root

(Willd.) Briq.

(Lamiaceae).

41 Corchorus olitorius L. Leaves (Malvaceae)

42 Cordia ecalyculata Vell Whole plant (Boraginaceae)

43 Cornus officinalis Rhizome Siebold \& Zucc.

(Cornaceae)

44 Cucumis melo (Cucurbitaceae)

Fruit peel

Cyamopsis

Beans

tetragonoloba (L.)

Taub

(Leguminosae)

46 Dimocarpus longans Flower

Leenh

(Sapindaceae)

Dioscoreae tokoronis Root

Linn

(Dioscoreaceae)
C. quinoa extract attenuate mRNA levels of several inflammation markers including monocyte chemotactic protein-1, CD68 and insulin resistance osteopontin, plasminogen activator inhibitor-1 and it also reverses the effects of HF-induced downregulation of the uncoupling protein(s) mRNA levels in muscle.

C. brevicaule inhibits fatty acid synthase and suppress the differentiation and lipid accumulation and affecting transcription factors such as SREBP-1c, C/EBP $\alpha$, and PPARy known to control the fatty acid synthase expression.

mRNA expression levels of lipogenesis rrelated genes such as SREBP1C, FAS and ACC1 in the liver are lowered and the size of adipocytes are reduced.

Phosphorylation levels of AMPK and acetyl-CoA carboxylase are decreased.

Mice fed with standard low-fat or a high-fat diet

C57BL/6 mice that were fed a high-fat diet

High fat diet induced mice

It nhibits pancreatic lipase activity. The extract contains $\beta$-sitosterol.

Reduces body weight, food intake, organ and fat pads weight and serum GLU, CHO, TRG, LDL and VLDL cholesterol levels and increases HDL levels.

Reduces weight of adipose pads and the serum levels of triglycerides, total cholesterol, and low density lipoprotein cholesterol.

High-fat diet induced obese [69] C57BL/6 mice

High fat diet induced obesity in C57BL/6J mice

Cafeteria diet and Atherogenic diet induced obesity in female rats.

High-calorie/high-fat-diet induced obesity SpragueDawley male rats

C. arabica diet supplementation can impair glucose

High-carbohydrate, high-fat [73] tolerance, hypertension, cardiovascular remodeling, and diet-fed Wistar male rats nonalcoholic fatty liver disease.

C. forskohlii act as anti-obesisity drug by inhibiting

Diet-induced obesity in rats $[74,75]$ dyslipidemia.

Liver tissue gene expression of gp91phox (NOX2) involved High fat diet - induced LDL in oxidative stress is down-regulated by $C$. olitorius and genes related to the activation of $\beta$-oxidation like PPAR $\alpha$ receptor deficient mice and CPT1A are up-regulated by the plant.

Anti-obesity activity of the $C$. ecalyculata is medicated by Mice (albino, swiss anorectic central action, facilitating binding to adenosine strain) treated with receptors, thereby promoting an extension of adrenalin. cyclophosphamide

Platycodin $D$ is the major component effective to activate $C 57 \mathrm{BL} / 6 \mathrm{~J}$ mice were fed a AMPK- $\alpha$. The extract reduces serum levels of aspartate HF diet transaminase and alanine transaminase.

C. melo reduces gain in body weight, serum lipid profile High cholesterol diet like total cholesterol, triglyceride, LDL-C level, atherogenic induced in rats index and increases serum HDL-C levels.

It decreases adipose triglyceride accompanied by High-fat-fed Wistar rats enhancing activity of hormone-sensitive lipase-facilitating mobilization of depot fat.

By combined effect of decreased exogenous lipid absorption, normalization of hepatic PPAR- $\gamma$ gene expression, suppression of pancreatic activity and SREBP$1 \mathrm{c}$ and FAS gene expression, and higher fecal triglyceride output.

It decreases triglyceride, total plasma cholesterol, and low-density lipoprotein-cholesterol. It suppresses the expression of SREBP-1 as well as that of fatty acid synthase in adipose and liver tissues.
Hyper caloric diet- male Sprague-Dawley rats.

High fat diet - induced mice [82] 

Oliv

(Eucommiaceae)

49 Fraxinus excelsior L. Seed (Oleaceae)

Garcinia cowa Roxb. Fruit, ex Choisy (Clusiaceae) commercially available tablet

51 Geranium thunbergii Leaf

Siebold ex Lindl. \&

Paxton

(Geraniaceae)

52 Glycine max (L.)Merr. Bean (Leguminosae)

Gymnema sylvestre Leaves (Retz.) R.Br. ex Sm

(Apocynaceae)

54 Hibiscus cannabinus L. Leaves (Malvaceae)

55 Hibiscus sabdariffa L. Leaf (Malvaceae)

Holoptelea integrifolia Bark (Roxb.) Planch.

(Ulmaceae)

Humulus lupulus L.

Female (Cannabaceae) inflorescence

Hunteria umbellata Seed (K.Schum.) Hallier $\mathrm{f}$. (Apocynaceae)

59 Hypericum philonotis Leaves Schltdl. \& Cham.

(Hypericaceae)

60 Hypericum silenoides Leaves Juss.

(Hypericaceae)

61 Ilex paraguariensis A.St.-Hil.

(Aquifoliaceae)

Leaves and unripe fruits

62 Ipomoea batatas (L.) Fruit Lam

(Convolvulaceae)

63 Saccharina japonica (Phaeophyceae)

Whole Plant
Asperuloside increases adenosine 5 '-triphosphate production in WAT and increases use of ketone bodies/ glucose in skeletal muscle.

Secoiridoids present enhances fat metabolism through $\beta$-oxidation, inhibit adipocyte differentiation during animal growth and limit fat accumulation.

Inhibits the enzyme ATP-dependent citrate lyase, which catalyzes the cleavage of citrate to oxaloacetate and acetyl-CoA.Serum apo A1 levels are increased by the plant and the serum total cholesterol levels.

The extract ameliorates high-fat diet-induced obesity by altering the adipokine levels and downregulates expression of transcription factors and lipogenic enzymes involved in lipid metabolism.

Reductions glucose-6-phosphate dehydrogenase, malic enzyme, fatty acid synthetase, as well as acetyl-CoA carboxylase. The extract decreases appetite and HF diet-induced body weight gain through leptin-like STAT3 phosphorylation and AMPK activation.

Inhibits serum lipids, leptin, insulin, glucose, apolipoprotein B and LDH levels while it increases the HDL-cholesterol, apolipoprotein A1 and antioxidant enzymes levels.

It decreases serum cholesterol, triglycerides, LDL-C, SGOT and SGPT activities.

Promotes $\mathrm{LXR} \alpha / \mathrm{ABCA} 1$ pathway, stimulating cholesterol removal from macrophages, delaying atherosclerosis. Also, the extract treatment attenuated liver steatosis, downregulated SREBP-1c and PPAR- $\gamma$, blocked the increase of IL-1, TNF- $\alpha$ mRNA and lipoperoxidation and increased catalase $\mathrm{mRNA}$

HMG-CoA reductase activity is reduced and cholesterol biosynthesis and increase in lecithin, cholesterolacyltransferase activity.

Hepatic fatty acid synthesis is reduced through the reduction of hepatic SREBP1c mRNA expression in the rats fed a high-fat diet.

The extract reduces weight gain pattern and causes dose related reductions in the serum lipids, Coronary artery risk index. Also, pre-treatment significantly improves triton-induced hepatic histological lesions.

Decreases body weight and serum glucose levels. It also Male Wistar rats fed with decreases total cholesterol, triglycerides and high-density high fat diet lipoprotein-cholesterol without changing low-density lipoprotein-cholesterol, AI, AST and ALT level.

Body weight and serum glucose levels of the rats

Male Wistar rats fed with decreased. The drug also has effect on total cholesterol, high fat diet triglycerides and high-density lipoprotein-cholesterol.

Down-regulates expression of Creb- 1 and C/EBPa, and

High fat diet- induced mice, [102-105] up-regulates expression of Dlk1, Gata2, Gata3, KIf2, Lrp5, male Wistar rats fed diet Pparc $_{2}$, Sfrp1, Tcf7l2, Wnt10b, and Wnt3a. The mRNA levels of PPAR- $\gamma 2$ were downregulated.

Expression of SREBP-I, Acyl-CoA Synthase, Glycerol-3Phosphate Acyltransferase, HMG-CoA Reductase and Fatty Acid Synthase in liver tissue in mice is altered. Expression of the fat intake-related gene ACC2 and lipogenesis-related genes are reduced. It increases phosphorylation of AMPK and its direct downstream protein, acetyl coenzyme A carboxylase.
Obesity induced by

$[83,84]$

Wistar rats, rats fed a highfat diet.

High fat diet induced mice

Female Sprague-Dawley rats fed atherogenic diet

High fat diet-induced obesity in wistar rats

igh cholesterol diet albino rats

High fat diet-induced obese $[95,96]$ C57BL/6NHsd mice

High-fat diet induced obese $[98,99]$ rat, male $\mathrm{C} 57 \mathrm{BL} / 6 \mathrm{~J}$ mice fed a HF diet

High fat diet- induced rats [100]
Mice fed with high-fat diet

[106]

High-fat-diet-induced
Dawley rats 
64 Larix laricina (Du Roi) K.Koch (Pinaceae) Ligularia fischeri Leaves (Ledeb.) Turcz. (Compositae) Ligustrum lucidum Fruits W.T.Aiton (Oleaceae)

67 Lithocarpus Leaves polystachyus (Wall. ex A.DC.) Rehder (Fagaceae).

68 Lithospermum erythrorhizon

Siebold \& Zucc. (Boraginaceae) (Rubiaceae)

Morus alba $\mathrm{L}$.

Fruit, leaves (Moraceae)

Morus australis Poir Fruit (Moraceae)

72 Morus nigra L. (Moraceae)

Fruit, leaves,

si

\section{Proinflammatory cytokines MCP-1 and TNF- $\alpha$, plasma} triglyceride, liver lipid peroxidation levels and adipocyte size are decreased. Inflammatory markers (monocyte chemoattractant protein-1, inducible nitric oxide synthase, C-reactive protein, tumour necrosis factor- $\alpha$ and interleukin-1) in liver and adipose tissue are increased.

73 Murraya koenigii (L.) Leaves Spreng.

(Rutaceae)

$74 \quad$ Myrciaria dubia Fruit (Kunth) McVaugh (Myrtaceae)

75 Myrtus communis L. Leaves (Myrtaceae)

$76 \quad$ Nelumbo nucifera Gaertn.

(Nelumbonaceae)

Stimulates glucose uptake, potentiated adipogenesis, activated AMPK, and acted as mitochondrial uncoupler/ inhibitor (on normal isolated mitochondria).

Polyphenols present in the extract exhibits antiobesity effects by inhibiting pancreatic lipase.

Treatment with the extract decreases HFD-induced obesity, mainly by improvin

Decreases levels of serum lipids, attenuates body weight gain and lowers circulatingleptin and insulin levels, ameliorate the state of oxidative stress, raise serum adiponectin, reduce circulating CRP and resistin levels, and depresses expression of PPARy and C/EBP $\alpha$.

Reduces high-fat diet-induced increases in body weight, white adipose tissue mass, serum triglyceride and total cholesterol levels, and hepatic lipid levels and decreases lipogenic and adipogenic gene expression. Acetylshikonin, active constituent of $L$. erythrorhizon suppresses adipocyte differentiation and attenuates adipogenic transcription factor expression.

Reduces body weight and fat mass. It increases glucose tolerance and reduced plasma triglycerides level.

The hepatic peroxisome PPAR-R and carnitine palmitoyltransferase-1 are elevated, while fatty acid 3-hydroxy-3-methylglutaryl-coenzyme A (HMG-CoA) reductase are reduced. It decreases hepatic lipids, fatty acid synthase and 3-hydroxy-3-methylglutaryl(HMG-CoA) reductase and elevates hepatic peroxisome PPAR- $\alpha$ and carnitine palmitoyltransferase- 1 . Reduces body weight gain, plasma total cholesterol and triglyceride levels in mice.

Reduces animal body weights of the fat in white adipose tissues, glucose, total cholesterol, triglycerides, and LDL-c and insulin blood levels. An increase in HDL-c levels also seen.

The body weight reduced by $32 \%$ when administered with sibutramine, while it was reduced by $21 \%$ and 24 $\%$ when administered with the methanolic extract of $M$. communis/kg body weight.

Seed epicarp, The extracts effective in inhibiting preadipocyte leaves, seed, differentiation. The flavonoids inhibits effect on both petals adipocyte differentiation and pancreatic lipase activity, accumulation and decreases expression PPARY, GLUT4, and leptin in cultured human adipocytes, indicating that it inhibits the differentiation of pre-adipocytes into adipocytes. The methanol extract inhibits lipase activity and suppresses the expression of fatty acid synthase, acetyl-CoA carboxylase, and HMGCoA reductase and increases the phosphorylation of AMP-activated protein kinase in the liver.
Diet-induced obese

C57BL/6 mice

C57BL/6 mice

High fat-diet-induced

C58BL/6J obese mice

High fat diet-induced obese [112] rats

C57BL/6J mice were fed a

$[113,114]$ normal or high-fat diet

High-fat diet-induced obesity in mice

High fat diet- induced mice, [116] 6-week-old male hamsters.

Male C57BL/6 mice fed with high-fat diet

Adenovirus 36-induced obesity in mice, high-fat (HF) diet-induced obese mice.

High fat diet -induced mice

Wistar rats with obesity induced by subcutaneous injection of monosodium glutamate High-fat diet induced obese [123] mice

High fat diet- induced mice [124-127] Male Sprague-Dawley rats were fed with a normal diet and a high-fat diet, High fat diet - induced C57BL/6 mice. 
Nephelium lappaceum Fruit

L.

(Sapindaceae)

raria retusa

(Forssk.) Asch

Shoot

(Nitrariaceae)

79 Olea europaea L. Leaves (Oleaceae)

Orthosiphon aristatus Whole plant

(Blume) Miq

(Lamiaceae)

81 Panax ginseng

Root

C.A.Mey.

(Araliaceae)

(L.) Britton

(Lamiaceae)

83 Petasites japonicus

(Siebold \& Zucc.)

Flower buds

Maxim.

(Compositae)

84 Phaseolus vulgaris L. Bean

(Leguminosae)

85 Phyllostachys edulis Leaves

(Carrière) J.Houz.

(Poaceae)

Pinus koraiensis Leaves

Siebold \& Zucc

(Pinaceae)

Piper fragile Benth Seed

(Piperaceae)

Piper sarmentosum leaves

Roxb.

(Piperaceae)

89 Platycodon grandiflorum

(Campanulaceae)

Polygonum aviculare Aerial Parts

L.

(Polygonaceae)

Populus balsamifera L. Whole Plant (Salicaceae)
The expression of Igf- 1 and Igf-1R were reduced on obese Rat fed with high calorie rat model treated with extract of $N$. lappaceum.

diet and treated with

ellagic acid

The extract supresses increase in body and fat mass weight, and decreases triglycerides and LDL-cholesterol levels and enhances gene expression related to lipid homeostasis in liver showing anti-obesity actions.

The extract reverses HFD-induced upregulation of WNT10b- and galanin-mediated signaling molecules and key adipogenic genes (PPARy, C/EBP $\alpha, C D 36, F A S$, and leptin). It also induces downregulation of thermogenic genes involved in uncoupled respiration (SIRT1, PGC1 $\alpha$, and UCP1) and mitochondrial biogenesis (TFAM, NRF-1, and $\operatorname{COX} 2$ ).

Betulinic acid, the active constituent suppresses

BKS.Cg-Dock7 $7^{\mathrm{m}}+/+$ Lepr $^{\mathrm{db} / \mathrm{J}}$

mice model

High-fat diet-induced

obesity in mice

hypothalamic protein tyrosine phosphatase $1 \mathrm{~B}$ in mice and enhances the antiobesity effect of leptin in obese rats

Ginsam increases PPAR- $\gamma$ expression and AMP-activated protein kinase phosphorylation in liver and muscle. The extracts strongly activates Hormone Specific Lipase via Protein Kinase A.

It decreases body weight gain, food efficiency ratio, and relative liver and epididymal fat mass.

The extracts attenuate three adipogenetic transcription factors, peroxisome PPAR- $\nu 2$, CCAAT/ enhancer- binding protein and sterol regulatory element- binding protein $1 \mathrm{c}$.

It reduces food intake and body weight in an animal

Genetically obese adult model of obesity resulting in suppression of glycaemia.

The extract ameliorates elevated MCP-1 concentration in the blood.

male Zucker fa/fa rats.

High fat diet - induced

C57BL/6J mice

Suppresses fat accumulation and intracellular triglyceride associated with downregulation of adipogenic

High fat diet Male Sprague-

Insulin - resistant rat, high

induced obese

High fat diet - induced rats

Diet- induced obesitytranscription factor expression, including PPAR $y$ and CEBP $\alpha$ in the differentiated 3T3-L1 adipocytes. It attenuates expression of FABP and GPDH as target genes of PPARY during adipocyte differentiation.

$P$. fragile rude oil shows significant reduction in body weight.

Male Sprague dawley mice [140] were treated with high cholesterol diet

Ovariectomy-Induced

$P$. sarmentosum group shows reduction in enzyme activity. Aqueous extract of $P$. fragile have the ability to reduce $11 \beta-H S D 1$ enzyme activity.

Platycodin feeding increases cholesterol absorption up to Golden Syrian hamsters $60 \%$, but not cholesterol synthesis. Platycodin-enriched diets can lower circulating and whole body cholesterol contents.

Extract of $P$. aviculare suppresses the elevated mRNA expression levels of sterol regulatory element-binding protein-1c, peroxisome PPAR- $\gamma$, fatty acid synthase, and adipocyte protein 2 in the white adipose tissue of obese mice.

Salicortin reduces whole body and retroperitoneal fat C57BI/6 mice subjected to [144] pad weights, as well as hepatic triglyceride accumulation. high fat diet It also modulates key components in signaling pathways involved with glucose regulation and lipid oxidation in the liver, muscle, and adipose tissue. 
Premna integrifolia Roots

Linn

(Verbenaceae)

93 Prunus mume

Zucc

(Rosaceae)

\section{Pueraria montana}

var. chinensis (Ohwi)

Sanjappa \& Pradeep (Leguminosae)

95 Punica granatum L Leaves, seed (Lythraceae) (Siebold) Siebold \&
Flower

Fruit

(

A significant decrease in the levels of serum glucose, triglyceride, total cholesterol, LDL and VLDL observed in the animals treated with the extract of $P$. integrifolia. Increases CPT-1 expression and decreases FAS, ACC, and SREBP-1C in the liver and quadriceps muscles to resulting in reducing triglyceride accumulation. It also improves insulin sensitivity in OVX rats and prevents the impairment of energy, lipid, and glucose metabolism by OVX through potentiating hypothalamic leptin and insulin signaling.

It downregulates acetyl-CoA carboxylase expression. For adipose tissue, the expressions of hormone-sensitive lipase in white adipose tissue and uncoupling protein 1 in brown adipose tissue are upregulated.

Punicic acid binds and activates PPAR- $\alpha$ and $\gamma$, thus upregulating PPAR $\alpha$ and its responsive genes (StearoylCoA desaturase-1, SCD1; Carnitine palmitoyltransferase 1, Cpt-1; and acyl-coenzyme A dehydrogenase) as well as PPAR $p$-responsive genes expression (CD36 and Fatty Acid Binding Protein4, FABP4) in intra-abdominal white adipose tissue while suppressing expression of the inflammatory cytokine TNF- $\alpha$ and NF-KB activation. It inhibits peroxisome PPAR $-\nu$ transactivity and the expression of its target genes, suggesting that rhein acts as a PPARy antagonist.

It decreases circulating tumor necrosis factor alpha, IL$1 \beta$, and leptin, and upregulated adiponectin. The extract also induces phase I and phase II gene expression and the peroxisome PPAR- $\gamma$ coactivator 1 -alpha. Serum triglycerides, cholesterol and insulin levels are also decreased in the lean animals.

98 Rubus fruticosus L. Fruit (Rosaceae)

Sapindus emarginatus Pericarp of

Vahl flower (Sapindaceae)

100 Sasa quelpaertensis Leaves Nakai

(Poaceae)

101 Schisandrachinensis Peel (Turcz.) Baill.

(Schisandraceae)

102 Senna siamea (Lam.) Roots H.S.Irwin \& Barneby (Leguminosae)

103 Shorea robusta Gaertn Leaves (Diptercarpaceae)

104 Sida rhombifolia L. Leaf (Malvaceae) L. (Solanaceae)
Purified blueberry anthocyanins have been shown to improve body weight and body composition and reduce obesity in mice.

Methanolic extract decreases body weight, BMI, Blood glucose levels, total cholesterol, LDL-C, HDL-C, Triglycerides, SGOT, and SGPT.

Adipogenesis is inhibited by this drug by downregulating the expression of CCAAT/enhancer-binding protein $\alpha$, peroxisome PPAR- $\gamma$, SREBP-1c, and aP2. It also decreases the expression of fatty acid synthase and adiponectin mRNAs in differentiating adipocytes. It increases AMPK and acetyl-CoA carboxylase phosphorylation.

It decreases expression of $\mathrm{C} / \mathrm{EBP} \beta, \mathrm{C} / \mathrm{EBP} \alpha$ or PPAR $\gamma$, and resultant down-regulation of the terminal marker gene, aP2 during differentiation of 3T3-L1 preadipocytes into adipocytes. Akt and GSK3 $\beta$ phosphorylation are down-regulated blocking adipogenesis and adipocyte differentiation.

Active constituents includes chrysophanol, physcion, emodin, cassiamin A, friedelin and cycloart-25-en-3,24diol exhibits pancreatic lipase inhibitory activity.

It decreasesserum glucose, triglyceride, cholesterol, LDL-C, HDL-C, VLDL-C, atherogenic index, SGPT and SGOT. Up-regulation of PPAR 2 and SREBP-1c expression in the epididymal adipose tissue, leading to attenuation of adipogenesis.

AMP-activated protein kinase and acetyl-CoA carboxylase phosphorylation in liver is elevated, and HMG-CoA reductase expression is decreased. It strongly decreases expression of peroxisome PPAR- $\gamma$, CCAAT/enhancerbinding protein alpha and perilipin in the adipose tissue.
Female Swiss Albino mice, [145] fed with cafetaria diet

High fat diet, ovariectomized rats

Male C57BL/6J mice were [146] fed a high-fat diet

High-fat diet induced obese $[147,148]$ mice

Diet-induced obese female $[108,149$, C57BL/6 mice

Lean (Le, $f a /+)$ and obese

$(\mathrm{Ob}, \mathrm{fa} / \mathrm{fa}$ ) female Zucker rats

\section{C57BL/6J}

mice fed a high-fat diet

Monosodium glutamate induced obesity in wistar albino rats

High-fat diet-induced obese C57BL/6 mice

HFD-induced obese rats

Alloxan induced diabetes rats.

Monosodium glutamate induced obesity in albino rats High fat diet- induced C57BL/6J mice

High-fat-diet-induced obesity in C57BL/6 mice 
106 Syzygium aromaticum Flower buds (L.) Merr. \& L.M.Perry

(Myrtaceae)

107 Tamarindus indica $\mathrm{L}$. (Leguminosae) seed coat

108 Tecomella undulata Bark (Sm.) Seem.

Vaccinium Peel corymbosum L. (Ericaceae)

\section{Veratrum nigrum L.} (Melanthiaceae)

111 Vigna angularis (Willd.) Ohwi \& H. Ohashi (Leguminosae)

\section{Vigna nakashimae}

Seeds

(Ohwi) Ohwi \& H.

Ohashi

(Leguminosae)

113 Viscum album L. Leaves, stems,

(Santalaceae) and fruits

114 Vitis thunbergii Siebold \& Zucc (Vitaceae)

115 Vitis vinifera $\mathrm{L}$. Seed flours,

\section{Roots}

116 Zanthoxylum

\section{Ziziphus mauritiana Bark}

(Vitaceae) Fruit bungeanum Maxim. (Rutaceae) Lam (Rhamnaceae)

peel, roots, fruit

\section{Mixp1, Stat5a, Hsl, Plin1, and Vdr were down-regulated.} The extract treatment decreases expression of aP2, Fas, and Tnfa, known markers of adipogenesis, as measured by real-time polymerase reaction. Expression of PPAR- $\gamma$ in liver and adipose tissue is lowered by regulating the lipid metabolism and suppressed obesity.

It reduces weight gain, white adipose tissue mass, and serum triglyceride and cholesterol levels. It also decreased lipid accumulation and PPAR $\gamma, C / E B P \alpha$, SREBP-1, and FAS protein and $m R N A$ levels in the liver. It reduces body weight, fat mass and pancreatic lipase activity.

\section{Dohaekseunggi-tang consists of five herbs including} Glycyrrhizae uralensis Fischer ( $40 \mathrm{~g})$, Rheum undulatumLinne (80 g), Prunus persica Linne (60 g), Cinnamomum cassia Presl $(40 \mathrm{~g})$, and Natrii Sulfas (40 g) mixed. The extract decreased serum total cholesterol, LDL-cholesterol, triglyceride,

traditional plantbased medicine (Taohe Chengqi Tang: formula Chinese) glucose, and leptin concentrations, and increased HDLcholesterol and adiponectin levels and increased mRNA expression of peroxisome proliferator activated receptor- $\gamma$, uncoupling protein-2, and adiponectin in visceral adipose tissue of HFD mice
High fat diet fed mice lipoprotein, with the concomitant reduction of body weight.

eptin and LPL levels in preadipocytes and adipocytes and

High-fat diet-
obese rats the differentiation of preadipocytes into adipocytes. It downIt reduces weight gain and the fat pad weight in high fat

High-fat diet-induced obese mice

High fat diet-induced extract significantly decreases triglyceride accumulation, inflammatory responses without affecting cell viability. activated receptory and its target genes. It enhances the High-fat diet fed mice phosphorylation of AMP-activated protein kinase (AMPK) and acetyl CoA carboxylase (ACC), and increases the examination indicates an amelioration of fatty liver. It Activation of AMPK activating glucose and lipid high-fat diet

High-fat diet-fed [171]

\section{C57BL/6JNarl mice}

Male Golden Syrian

hamsters fed high-fat (HF) diets, high fat diet induced C57BL/6J mice

By up-regulating hepatic genes related to cholesterol (CYP51) and bile acid (CYP7A1) synthesis as well as LDLcholesterol uptake. Lipid metabolism-associated genes

(n)

Obese C57BL/6 mice fed a

high-fat diet

High Fat Diet induced

obesity in Wistar rats

High-fat diet induced obese [181] 
Table 2. Anti-obesity effect of plants with mechanism of action studied on cell line as model.

\begin{tabular}{|c|c|c|c|c|c|}
\hline 1 & $\begin{array}{l}\text { Acorus calamus Linn } \\
\text { (Araceae) }\end{array}$ & $\begin{array}{l}\text { Rhizome, roots } \\
\text { and leaves }\end{array}$ & $\begin{array}{l}\text { Ethyl acetate extract of } A \text {. calamus inhibits } \\
\alpha \text {-glucosidase activity. }\end{array}$ & HTT-T15 cell line & [25] \\
\hline 2 & $\begin{array}{l}\text { Aegle marmelos Linn } \\
\text { (Rutaceae) }\end{array}$ & Leaves & $\begin{array}{l}\text { Active compounds umbelliferone and esculetin } \\
\text { depletes lipid content in the adipocytes and by } \\
\text { decreasing the hyperlipidemia in obese rats fed with } \\
\text { high-fat diet. }\end{array}$ & 3T3-L1 preadipocytes & {$[30,31]$} \\
\hline 3 & $\begin{array}{l}\text { Agrimonia pilosa Ledeb } \\
\text { (Rosaceae) }\end{array}$ & Aerial parts & $\begin{array}{l}\text { Active constituent } 1 \text { beta-hydroxy-2-oxopomolic acid } \\
\text { inhibits adipocyte differentiation and expression } \\
\text { of adipogenic marker genes, such as PPAR- } \gamma, \mathrm{C} / \\
\text { EBPalpha, GLUT4, adiponectin, aP2, ADD1/SREBP1c, } \\
\text { resistin, and fatty acid synthase. It also inhibits } \\
\text { adipocyte differentiation through downregulation } \\
\text { of various adipocytokines by blocking PPAR- } \gamma \text { and C/ } \\
\text { EBPalpha expression. }\end{array}$ & 3T3-L1 preadipocytes & [182] \\
\hline 4 & $\begin{array}{l}\text { Alnus hirsuta } \\
\text { (Spach) Rupr. } \\
\text { (Betulaceae) }\end{array}$ & Leaves & $\begin{array}{l}\text { Platyphyllonol-5-O- } \beta-d-x y l o p y r a n o s i d e ~ s u p p r e s s e s \\
\text { the induction of PPAR } y \text { and } C / E B P \alpha \text { protein } \\
\text { expression, and inhibits adipocyte differentiation. }\end{array}$ & 3T3-L1 preadipocyte cells & [183] \\
\hline 5 & $\begin{array}{l}\text { Amomum cardamomum } \\
\text { L. } \\
\text { (Zingiberaceae) }\end{array}$ & Seeds & $\begin{array}{l}\text { By regulating the } C / E B P \alpha, C / E B P \beta \text { and PPARy gene } \\
\text { and protein expressions. }\end{array}$ & 3T3-L1 Cell lines. & [184] \\
\hline 6 & $\begin{array}{l}\text { Bauhinia variegate L. } \\
\text { (Fabaceae) }\end{array}$ & $\begin{array}{l}\text { Flowers, flower } \\
\text { buds, stem, } \\
\text { roots, stem bark, } \\
\text { seeds, leaves }\end{array}$ & $\begin{array}{l}\text { it reduces increased level of total cholesterol, } \\
\text { triglycerides, LDLP and increases the level of HDLP, } \\
\text { brain serotonin level. } \beta \text {-sitosterol in the stem } \\
\text { induces secretion of serotonin in brain and in turn } \\
\text { exhibits anti-obesity activity. }\end{array}$ & Human neutrophils. & [185] \\
\hline 7 & $\begin{array}{l}\text { Brassica rapa L. } \\
\text { (Brassicaceae) }\end{array}$ & Root & $\begin{array}{l}\text { Lipolysis-related genes including } \beta_{3} \text {-adrenergic } \\
\text { receptor, hormone-sensitive lipase, adipose } \\
\text { triglyceride lipase, and uncoupling protein are } \\
\text { induced in white adipocytes of animals treated with } \\
\text { extract of B. campestris. Activation of cyclic AMPK, } \\
\text { HSL, and extracellular signal-regulated kinase are } \\
\text { induced in EBR-treated 3T3-L1 cells. }\end{array}$ & 3T3 adipocytes. & {$[52]$} \\
\hline 8 & $\begin{array}{l}\text { Caesalpinia sappan L. } \\
\text { (Leguminosae) }\end{array}$ & Heartwood & $\begin{array}{l}\text { Brazilein inhibits intracellular lipid accumulation } \\
\text { during adipocyte differentiation in 3T3-L1 cells and } \\
\text { suppresses the induction of peroxisome PPAR- } \gamma \\
\text { (PPAR }) \text {. }\end{array}$ & $\begin{array}{l}\text { Postconfluent 3T3-L1 } \\
\text { preadipocytes }\end{array}$ & [186] \\
\hline 9 & $\begin{array}{l}\text { Citrus aurantium L. } \\
\text { (Rutaceae) }\end{array}$ & Fruits, leaves & $\begin{array}{l}\text { It inhibits Akt activation and GSK3 } \beta \text { phosphorylation, } \\
\text { which induces the down-regulation of lipid } \\
\text { accumulation and lipid metabolizing genes, } \\
\text { ultimately inhibiting adipocyte differentiation. }\end{array}$ & 3T3-L1 preadipocytes & {$[22,187,188]$} \\
\hline 10 & $\begin{array}{l}\text { Coptis chinensis } \\
\text { Franch. } \\
\text { (Ranunculaceae) }\end{array}$ & Rhizome & $\begin{array}{l}\text { It inhibits lipid accumulation in 3T3-L1 cells. The five } \\
\text { alkaloids present in this plant significantly reduces } \\
\text { expression levels of several adipocyte marker genes } \\
\text { including proliferator activated receptor and CCAAT/ } \\
\text { enhancer- binding protein. Isolated alkaloids found to } \\
\text { inhibit adipogenesis. }\end{array}$ & 3T3-L1 adipocytes cells & [189] \\
\hline 11 & $\begin{array}{l}\text { Cucurbita moschata } \\
\text { Duchesne } \\
\text { (Cucurbitaceae) }\end{array}$ & Stems & $\begin{array}{l}\text { Reduces expression of peroxisome PPAR- } \gamma \text {, CCAAT/ } \\
\text { enhancer-binding protein } \alpha \text {, fatty acid-binding } \\
\text { protein } 4 \text {, sterol response element-binding protein- } \\
1 c \text { and stearoyl-coenzyme A desaturase- } 1 \text {, and } \\
\text { decreases lipid accumulation. }\end{array}$ & $\begin{array}{l}\text { Primary mouse embryonic } \\
\text { fibroblasts }\end{array}$ & {$[190]$} \\
\hline 12 & $\begin{array}{l}\text { Curcuma longa L. } \\
\text { (Zingiberaceae) }\end{array}$ & Rhizomes & $\begin{array}{l}\text { Increase hormone-sensitive lipase and adipose } \\
\text { triglyceride lipase mRNA levels and decreases } \\
\text { perilipin mRNA level via AMPK, resulting in lipolysis. } \\
\text { In adipose tissue, curcumin inhibits macrophage } \\
\text { infiltration and nuclear factor KB activation induced } \\
\text { by inflammatory agents. }\end{array}$ & 3T3-L1 adipocytes & {$[191,192]$} \\
\hline 13 & $\begin{array}{l}\text { Cyclopia falcata (Harv.) } \\
\text { Kies } \\
\text { (Leguminosae) }\end{array}$ & Stem & $\begin{array}{l}\text { Flavonoid, phloretin- } 3^{\prime}, 5^{\prime} \text {-di-C-glucoside inhibits } \\
\text { intracellular triglyceride and down regulates PPAR2 } \\
\text { expression and in in vitro condition it can inhibit } \\
\text { adipogenesis. }\end{array}$ & $\begin{array}{l}\text { 3T3-L1 mouse pre- } \\
\text { adipocytes }\end{array}$ & [193] \\
\hline 14 & $\begin{array}{l}\text { Cyclopia maculata } \\
\text { (Andrews) Kies } \\
\text { (Leguminosae) }\end{array}$ & Stems & $\begin{array}{l}\text { Mangiferin, hesperidin inhibits intracellular } \\
\text { triglyceride and fat accumulation, and decreases } \\
\text { PPAR2 expression and in in vitro it can inhibit } \\
\text { adipogenesis. }\end{array}$ & $\begin{array}{l}\text { 3T3-L1 mouse pre- } \\
\text { adipocytes }\end{array}$ & [193] \\
\hline
\end{tabular}




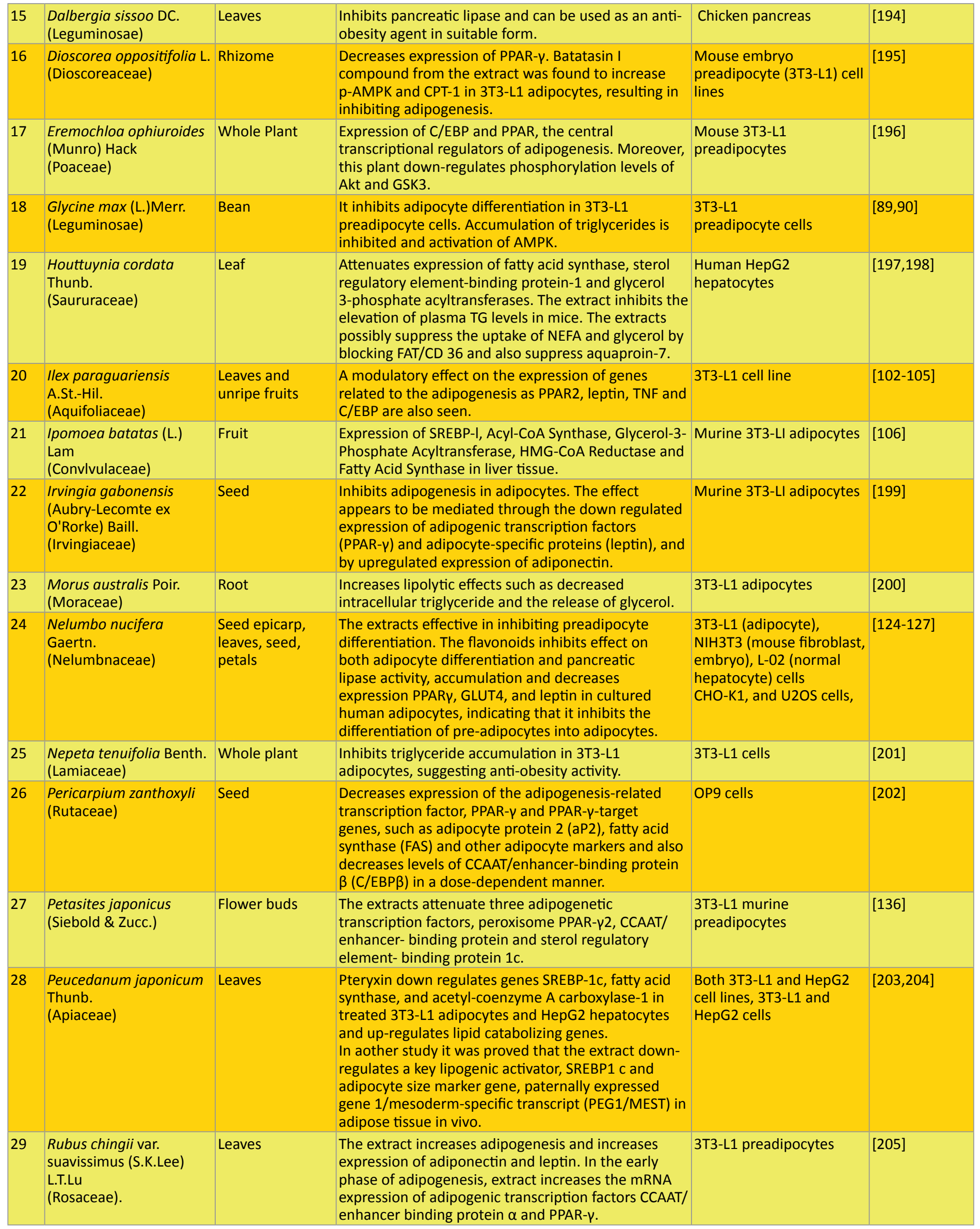


Salicornia herbacea L. Whole plant (Amaranthaceae) (n)

(n)

31 Siegesbeckia pubescenst. Whole plant (Amaranthaceae)

32 Smilax china L. (Smilacaceae)

33 Tetrapanax papyriferus Whole plant (Hook.) K.Koch

(Araliaceae)

34 Veratrum nigrum $\mathrm{L}$. (Melanthiaceae)

35 Vitis labrusca L. (Vitaceae)

36 Vitis vinifera $\mathrm{L}$. (Vitaceae) roots, fruit
Isorhamnetin 3-O- $\beta$-D-glucopyranoside suppresses adipogenic differentiation by downregulation of peroxisome proliferator-activated receptor- $\gamma$, CCAAT/enhancer-binding proteins, SREBP1, and the adipocyte-specific proteins. Specific mechanism mediating the effects of isorhamnetin 3-O- $\beta-D-$ glucopyranoside confirmed by activation of AMPK.

The anti-obesity effect is modulated by cytidinecytidine-adenosine-adenosine-thymidine/enhancer binding proteins, and peroxisome proliferatoractivated receptor, gene and protein expressions.

Polyphenol and flavonoid, exhibits $\alpha$-glucosidase and lipid accumulation inhibition properties.

The anti-obesity effect is modulated by cytidinecytidine-adenosine-adenosine-thymidine/enhancer binding proteins, and peroxisome proliferatoractivated receptor, gene and protein expressions.

It decreases lipid accumulation and the expressions of two major adipogenesis factors, PPAR and C/EBP, in 3T3-L1 cells.

The extract of $V$. labrusca inhibits lipid accumulation of $\mathrm{C} 3 \mathrm{H} 10 \mathrm{~T} 1 / 2$ and $3 \mathrm{~T} 3-\mathrm{L} 1$ cells in a dose-dependent manner. Inhibition is associated with reduced expression of PPAR- $\gamma$.

Seed flours, peel, By up-regulating hepatic genes related to cholesterol
(CYP51) and bile acid (CYP7A1) synthesis as well as LDL-cholesterol uptake. Lipid metabolism-associated genes Mlxp1, Stat5a, Hsl, Plin1, and Vdr were down-regulated. The extract treatment decreases expression of aP2, Fas, and Tnfa, known markers of adipogenesis, as measured by real-time polymerase reaction. Expression of PPAR- $\gamma$ in liver and adipose tissue is lowered by regulating the lipid metabolism and suppressed obesity.

37 Ziziphus jujube Mill. Fruit $\quad$ Suppresses lipid accumulation and glycerol-3(Rhamnaceae) phosphate dehydrogenase. Elicits the most inhibitory effect with attenuation of the expression of key adipogenic transcription factors, including PPAR- $\gamma$ and CCAAT enhancer binding proteins (C/EBPs) at the protein level.

38 Germinated brown rice, Seed germinated waxy brown rice, germinated black rice, and germinated waxy black rice Extract of these seeds decreases body weight gain and lipid accumulation in the liver and epididymal adipose tissue. The mRNA levels of adipogenic transcriptional factors, such as CCAAT enhancer binding protein (C/EBP)- $\alpha$, SREBP(SREBP)- $1 c$, and
3T3-L1 preadipocytes

[206]

3T3-L1 preadipocytes

[207]

T3-L1 adipocytes

[208]

3T3-L1 preadipocytes

[207]

3T3-L1 cells

C3H10T1/2 and 3T3-L1 cells

3T3-L1 preadipocytes, high fat diet- induced

[54,171-178] mice, murine 3T3-LI adipocytes,

3T3-L1 preadiocytes

[209-211] peroxisome proliferator activated receptors (PPAR)- $\nu$, and related genes (aP2, FAS) are decreased by the seed extract.

Table 3 List of plants exhibiting anti-obesity activity studied on human volunteers.

\begin{tabular}{|c|c|c|c|c|c|}
\hline 1 & $\begin{array}{l}\text { Carum carvi L. } \\
\text { (Apiaceae) }\end{array}$ & Seed & $\begin{array}{l}\text { Reduces weight, body mass index, body fat percentage, } \\
\text { and waist-to-hip ratio. }\end{array}$ & Human clinical trials & [213] \\
\hline 2 & $\begin{array}{l}\text { Cissus } \\
\text { quadrangularis L. } \\
\text { (Vitaceae) }\end{array}$ & $\begin{array}{l}\text { Cylaris a formula } \\
\text { contains a } C \text {. } \\
\text { quadrangularextract }\end{array}$ & $\begin{array}{l}\text { Phytosterols and fiber extracts have anti-lipase, and } \\
\text { anorexiant properties that reduce the absorption of } \\
\text { dietary fats and enhance satiation by increasing serum } \\
\text { serotonin levels. }\end{array}$ & Human clinical trials & [214] \\
\hline 3 & $\begin{array}{l}\text { Citrus aurantium L. } \\
\text { (Rutaceae) }\end{array}$ & Fruits, leaves & $\begin{array}{l}\text { The active constituent p-synephrine increases metabolic } \\
\text { rate, energy expenditure and increase in weight loss. } \\
\text { The leaf extract down-regulates the expression of } \\
\text { C/EBP } \beta \text { and subsequently inhibits the activation of } \\
\text { PPARY and C/EBP } \alpha \text {. The anti-adipogenic activity of is } \\
\text { mediated by the inhibition of Akt activation and GSK3 } 3 \\
\text { phosphorylation, which induces the down-regulation } \\
\text { of lipid accumulation and lipid metabolizing genes, } \\
\text { ultimately inhibiting adipocyte differentiation. }\end{array}$ & Human clinical trials & {$[22,187,188]$} \\
\hline
\end{tabular}




\begin{tabular}{|c|c|c|c|c|c|}
\hline 4 & $\begin{array}{l}\text { Garcinia cowa Roxb. } \\
\text { ex Choisy } \\
\text { (Clusiaceae) }\end{array}$ & $\begin{array}{l}\text { Fruit, commercially } \\
\text { available tablet }\end{array}$ & $\begin{array}{l}\text { Inhibits the enzyme ATP-dependent citrate lyase, which } \\
\text { catalyzes the cleavage of citrate to oxaloacetate and } \\
\text { acetyl-CoA.Serum apo A1 levels are increased by the } \\
\text { plant and the serum total cholesterol levels. }\end{array}$ & Human clinical trials & {$[86,87]$} \\
\hline 5 & $\begin{array}{l}\text { Gynostemma } \\
\text { pentaphyllum } \\
\text { (Thunb.) Makino } \\
\text { (Cucurbitaceae) }\end{array}$ & Leaves & $\begin{array}{l}\text { Activation of AMPK by 5-aminoimidazole-4- } \\
\text { carboxamide- 1-b-D-ribofuranoside (AICAR) inhibits } \\
\text { adipogenesis by downregulating PPARc and CEBP1a } \\
\text { as well as lipogenic factors including fatty acid binding } \\
\text { protein } 4 \text { and lipoprotein lipase. AMPK activation } \\
\text { directly inactivates ACC through Ser79 phosphorylation, } \\
\text { leading to decreased fat synthesis by reducing the } \\
\text { production of malonyl-CoA from acetyl-CoA. }\end{array}$ & Human clinical trials & [215] \\
\hline 6 & $\begin{array}{l}\text { Nigella sativa L. } \\
\text { (Ranunculaceae) }\end{array}$ & $\begin{array}{l}\text { Commercial Nigella } \\
\text { sativa oil prepared } \\
\text { by steam distillation. }\end{array}$ & $\begin{array}{l}\text { N. sativa reduces total cholesterol, low density } \\
\text { lipoprotein (LDL) and fasting blood glucose. The oil } \\
\text { is effective as an add-on therapy in patients with } \\
\text { metabolic syndrome. }\end{array}$ & Human Volunteer & {$[216,217]$} \\
\hline 7 & $\begin{array}{l}\text { Salacia reticulata } \\
\text { wight } \\
\text { (Celastraceae) }\end{array}$ & Root & $\begin{array}{l}\text { Significant weight and body-fat reduction was observed } \\
\text { in S. reticulata treated animals and also BMI reduction } \\
\text { is seen. }\end{array}$ & Human clinical trials & [218] \\
\hline 8 & $\begin{array}{l}\text { Trigonella foenum- } \\
\text { graecum L. } \\
\text { (Leguminosae) }\end{array}$ & Seed & $\begin{array}{l}\text { Daily fat consumption, expressed as the ratio fat } \\
\text { reported energy intake/total energy expenditure } \\
\text { (fat-REI/ TEE), is decreased in overweight subjects } \\
\text { administered the fenugreek seed extract. Significant } \\
\text { decrease in the insulin/glucose ratio in subjects treated } \\
\text { with fenugreek seed extract. }\end{array}$ & Clinical trials & [219] \\
\hline 9 & $\begin{array}{l}\text { Turnera diffusa } \\
\text { Willd. ex Schult. } \\
\text { (Passifloraceae) }\end{array}$ & Leaves & $\begin{array}{l}\text { The herbal preparation capsules delays gastric emptying, } \\
\text { reducing the time to perceived gastric fullness and } \\
\text { induces weight loss. }\end{array}$ & Healthy volunteers & {$[220,221]$} \\
\hline 10 & $\begin{array}{l}\text { Vernonia amygdalina } \\
\text { Delile } \\
\text { (Compositae) }\end{array}$ & Leaf & $\begin{array}{l}\text { Fat elimination usually occurred within } 2 \mathrm{sec}, 2 \mathrm{~min} \text { of } \\
\text { extract intake. The blood glucose lowers effects of } V \text {. } \\
\text { amygdalina leaf extract were usually exerted in } 2 \mathrm{sec}, 2 \\
\text { min of extract intake by the patient. }\end{array}$ & Clinical trials & [222] \\
\hline 11 & $\begin{array}{l}\text { Ziziphus jujube Mill. } \\
\text { (Rhamnaceae) }\end{array}$ & Fruit & $\begin{array}{l}\text { The extract suppresses lipid accumulation and glycerol- } \\
\text { 3-phosphate dehydrogenase. } Z \text {. jujuba extract elicits the } \\
\text { most inhibitory effect with attenuation of the expression } \\
\text { of key adipogenic transcription factors, including PPAR- } \gamma \\
\text { and CCAAT enhancer binding proteins (C/EBPs) at the } \\
\text { protein level. }\end{array}$ & Human clinical trials & [209-211] \\
\hline
\end{tabular}

Table 4. Anti-obesity effect of plants with mechanism of action studied on isolated cell organelles.

\begin{tabular}{|l|l|l|l|}
\hline Verbesina persicifolia Aerial parts & $4 \beta$-cinnamoyloxy, $1 \beta, 3 \alpha$-dihydroxyeudesm-7,8-ene is the active constituent \\
DC & $\begin{array}{l}\text { present in V. persicifolia induces bioenergetic collapse in rat liver mitochondria, } \\
\text { (Compositae) } \\
\text { demonstrating typical uncoupling agent. It acts as a mild uncoupler droping } \Delta \psi \\
\text { and increases respiratory state } 4 \text {. The energy collapse, mild uncoupling, and } \\
\text { the fact that } V \text {. persicifolia is largely used in folk medicines, this plant may be } \\
\text { viewed as a potentially effective anti-obesity drug. }\end{array}$
\end{tabular}

Table 5. Anti-obesity effect of plants with mechanism of action studied on isolated cell enzymes.

\begin{tabular}{|c|c|c|c|c|c|}
\hline 1 & $\begin{array}{l}\text { Fraxinus chinensis } \\
\text { subsp. rhynchophylla } \\
\text { (Hance) A.E.Murray } \\
\text { (Oleaceae) }\end{array}$ & $\begin{array}{l}\text { Stems and } \\
\text { barks }\end{array}$ & $\begin{array}{l}\text { Major active components are secoiridoids ligstroside, oleuropein, } \\
2 \text { "-hydroxyoleuropein and hydroxyframoside B. These compounds } \\
\text { significantly inhibit pancreatic lipase and hydroxyframoside B being the most } \\
\text { active inhibitor in a mixed mechanism of competitive and noncompetitive } \\
\text { manner. }\end{array}$ & $\begin{array}{l}\text { Porcine } \\
\text { pancreatic } \\
\text { lipase }\end{array}$ & [224] \\
\hline 2 & $\begin{array}{l}\text { Vitis vinifera L. } \\
\text { (Vitaceae) }\end{array}$ & $\begin{array}{l}\text { Seed flours, } \\
\text { peel, roots, } \\
\text { fruit }\end{array}$ & $\begin{array}{l}\text { By up-regulating hepatic genes related to cholesterol (CYP51) and bile acid } \\
\text { (CYP7A1) synthesis as well as LDL-cholesterol uptake. Lipid metabolism- } \\
\text { associated genes Mlxp1, Stat5a, Hsl, Plin1, and Vdr were down-regulated. } \\
\text { The extract treatment decreases expression of aP2, Fas, and Tnfa, known } \\
\text { markers of adipogenesis, as measured by real-time polymerase reaction. } \\
\text { Expression of PPAR- } \gamma \text { in liver and adipose tissue is lowered by regulating the } \\
\text { lipid metabolism and suppressed obesity. }\end{array}$ & $\begin{array}{l}\text { Pure } \\
\text { pancreatic } \\
\text { lipase }\end{array}$ & {$[54,171-178]$} \\
\hline
\end{tabular}

was an increase in metabolic rate and energy expenditure. It was also reported that the clinical trials performed on humans for the plant extracts $[151,165,226]$ showed an excess fat elimination, body mass index, fat percentage and blood glucose lowering effects. In another clinical trial study [148] the fenugreek seed extract decreased the fat consumption and also insulin/glucose ratio. The essential oil from the plants $[124,227]$ suppressed fat accumulation, intracellular triglyceride and decrease in body weight. Ginseng which is a popular Chinese herbal medicine significantly decreased the weight gain and improved glucose 
tolerance $[115,120]$. $P$. granatum exhibits potential antiobesity mechanism including inhibition of pancreatic lipase activity and suppression of energy intake. Its effect on energy intake was similar to subutramine but with a different mechanism.

A study reported that Green tea possessed higher antioxidant activity than antiobesity activity due to its high concentration of catechins, including epicatechins, ECG and EGCG. It was proved that antiobesity activity of catechins resulted from the combined actions of appetite reduction, greater lipolytic activity, energy expenditure and adipocyte differentiation.

The active compounds umbelliferone and esculetin from the plant Aegle marmelos have shown marked effect by depleting the lipid content in the adipocytes and by decreasing the hyperlipidemia. Similarly, galangin a compound from Alpinia galangal showed a significant decrease in serum lipids, liver weight, lipid peroxidation and accumulation of hepatic Triglycerides. Decursin a compound from Angelica gigas significantly improved glucose tolerance and reduced the secretion of HFD-induced adipocytokines. The phytoconstituent compound sitosterol found in Boerhaavia diffusa is structurally similar to cholesterol has been suggested to reduce cholesterol by lowering the level of LDL-cholesterol. p-synephrine compound from the plant Citrus aurantium showed increased metabolic rate, energy expenditure and increase in weight loss. In Nelumbo nucifera flavonoids showed mild inhibitory effect on both adipocyte differentiation and pancreatic lipase activity. Among the flavonoids, flavones without glucose inhibited pancreatic lipase activity, whereas flavone glycosides did not show inhibition. The presence of ephedrine and pseudoephedrine in the plant Sida rhomboidea induced appetite suppression that inhibits body weight gain.

\section{Conclusion}

Natural products identified from traditional medicinal plants have always paved the way for development of new types of therapeutics. Generally most of the compounds were isolated from natural sources despite which orlistat a semi-synthetic derivative of lipstatin have been approved by the US food and drug administration for the treatment of obesity. Orlistat is a potent inhibitor of pancreatic lipase (PL) which is a lipolytic enzyme which hydrolyses dietary fats in the initial step of lipid metabolism. There have been many reports on other effects such as anti-oxidative stress effects which may be important in the management of other diseases like cardiovascular diseases and diabetes. The antiobesity drugs are generally preferred based on high efficacy and effectiveness. The active exploration of natural sources has provided new developments based on the understanding of complex and redundant physiological mechanisms. Such exploration will lead to a safe and effective pharmacological treatment. 


\section{References}

Centre WM (2015) Obesity and overweigh. World Health Organization.

Devlin MJ, Yanovski SZ, Wilson GT (2000) Obesity: what mental health professionals need to know. Am J Psychiatry 157: 854-866.

Rosen ED, Walkey CJ, Puigserver P, Spiegelman BM (2000) Transcriptional regulation of adipogenesis. Genes Dev 14: 12931307.

Pagliassotti MJ, Gayles EC, Hill JO (1997) Fat and energy balance. Ann N Y Acad Sci 827: 431-448.

Mandrup S, Lane MD (1997) Regulating adipogenesis. J Biol Chem 272: 5367-5370.

Ducharme NA, Bickel PE (2008) Lipid droplets in lipogenesis and lipolysis. Endocrinology 149: 942-949.

Akiyama T, Tachibana I, Shirohara H, Watanabe N, Otsuki M (1996) High-fat hypercaloric diet induces obesity, glucose intolerance and hyperlipidemia in normal adult male Wistar rat. Diabetes Res Clin Pract 31: 27-35.

Yudkin JS (1999) C-reactive protein in healthy subjects: associations with obesity, insulin resistance, and endothelial dysfunction: a potential role for cytokines originating from adipose tissue? Arterioscler Thromb Vasc Biol 19: 972-978.

Freytag SO, Utter MF (1983) Regulation of the synthesis and degradation of pyruvate carboxylase in 3T3-L1 cells. J Biol Chem 258: 6307-6312.

10 Kim EJ, Jung SN, Son KH, Kim SR, Ha TY, et al. (2007) Antidiabetes and antiobesity effect of cryptotanshinone via activation of AMPactivated protein kinase. Mol Pharmacol 72: 62-72.

Klop B, Elte JW, Cabezas MC (2013) Dyslipidemia in obesity: mechanisms and potential targets. Nutrients 5: 1218-1240.

12 Kopelman PG (2000) Obesity as a medical problem. Nature 404: 635-643.

13 Matson KL, Fallon RM (2012) Treatment of obesity in children and adolescents. J Pediatr Pharmacol Ther 17: 45-57.

Bhutani KK, Birari RB, Kapat K (2007) Potential antiobesity and lipid lowering natural products: a review. Nat. Prod. Commun 2: 331-348.

Drew BS, Dixon AF, Dixon JB (2007) Obesity management: update on orlistat. Vasc Health Risk Manag 3: 817-821.

16 Tziomalos K, Krassas GE, Tzotzas T (2009) The use of sibutramine in the management of obesity and related disorders: an update. Vasc Health Risk Manag 5: 441-452.

Connolly HM, Crary JL, McGoon MD, Hensrud DD, Edwards BS, et al. (1997) Valvular heart disease associated with fenfluraminephentermine. N Engl J Med 337: 581-588.

8 James WP, Caterson ID, Coutinho W, Finer N, Van Gaal LF, et al. (2010) Effect of sibutramine on cardiovascular outcomes in overweight and obese subjects. N Engl J Med 363: 905-917.

Kang JG, Park CY (2012) Anti-Obesity Drugs: A Review about Their Effects and Safety. Diabetes Metab J 36: 13-25.

Glazer G (2001) Long-term pharmacotherapy of obesity 2000: a review of efficacy and safety. Arch Intern Med 161: 1814-1824.

Mayer MA, Höcht C, Puyó A, Taira CA (2009) Recent advances in obesity pharmacotherapy. Curr Clin Pharmacol 4: 53-61.
Moro CO, Basile G (2000) Obesity and medicinal plants. Fitoterapia 71 Suppl 1: S73-82.

Han LK, Kimura Y, Okuda H (2005) Anti-obesity effects of natural products. Studies in Natural Products Chemistry 2005 30: 79-110.

Rani N, Sharma SK, Vasudeva N (2012) Assessment of Antiobesity Potential of Achyranthes aspera Linn. Seed. Evid Based Complement Alternat Med 2012: 715912.

Mythili Avadhani MN (2013) The Sweetness and Bitterness of Sweet Flag [Acorus calamus L.] - A Review. Research Journal of Pharmaceutical, Biological and Chemical Sciences 4: 598-610.

Oh SD, Kim M, Min BI, Choi GS, Kim SK, et al. (2014) Effect of Achyranthes bidentata Blume on 3T3-L1 Adipogenesis and Rats Fed with a High-Fat Diet. Evid Based Complement Alternat Med 2014: 158018.

7 Sung YY, Yoon T, Yang WK, Moon BC, Kim HK (2013) Antiâ€'obesity effects of Actinidia polygama extract in mice with highâ€'fat dietâ€'induced obesity. Mol Med Rep 7: 396-400.

Hyun-Jin C, Mi Ja C, Seung-Shi H (2010) Antiobese and hypocholesterolaemic effects of an Adenophora triphylla extract in HepG2 cells and high fat diet-induced obese mice. Food Chemistry 119: 437-444.

Lee SE, Lee EH, Lee TJ, Kim SW, Kim BH (2013) Anti-obesity effect and action mechanism of Adenophora triphylla root ethanol extract in C57BL/ 6 obese mice fed a high-fat diet. Biosci Biotechnol Biochem 77: 544-550.

Karmase A, Birari R, Bhutani KK (2013) Evaluation of anti-obesity effect of Aegle marmelos leaves. Phytomedicine 20: 805-812.

Karmase A, Jagtap S, Bhutani KK (2013) Anti adipogenic activity of Aegle marmelos Correa. Phytomedicine 20: 1267-1271.

2 Kim OY, Lee SM, Do H, Moon J, Lee KH, et al. (2012) Influence of quercetin-rich onion peel extracts on adipokine expression in the visceral adipose tissue of rats. Phytother Res 26: 432-437.

Moon J, Do HJ, Kim OY, Shin MJ (2013) Antiobesity effects of quercetin-rich onion peel extract on the differentiation of 3T3-L1 preadipocytes and the adipogenesis in high fat-fed rats. Food Chem Toxicol 58: 347-354.

Sung YY, Yoon T, Kim SJ, Yang WK, Kim HK (2011) Anti-obesity activity of Allium fistulosum L. extract by down-regulation of the expression of lipogenic genes in high-fat diet-induced obese mice. Mol Med Rep 4: 431-435.

Chen YC (2014) Methanolic extract of black garlic ameliorates dietinduced obesity via regulating adipogenesis, adipokine biosynthesis, and lipolysis. Journal of Functional Foods 9: 98-108.

6 Kim I, Kim HR, Kim JH, Om AS (2013) Beneficial effects of Allium sativum L. stem extract on lipid metabolism and antioxidant status in obese mice fed a high-fat diet. J Sci Food Agric 93: 2749-2757.

7 Lai YS (2014) Garlic essential oil protects against obesity-triggered nonalcoholic fatty liver disease through modulation of lipid metabolism and oxidative stress. J Agric Food Chem 62: 5897-5906.

Kumar S, Alagawadi KR (2013) Anti-obesity effects of galangin, a pancreatic lipase inhibitor in cafeteria diet fed female rats. Pharm Biol 51: 607-613.

Jung CH, Jang SJ, Ahn J, Gwon SY, Jeon TI, et al. (2012) Alpinia officinarum inhibits adipocyte differentiation and high-fat dietinduced obesity in mice through regulation of adipogenesis and lipogenesis. J Med Food 15: 959-967. 
40 Xia DZ, Yu XF, Wang HM, Ren QY, Chen BM (2010) Anti-obesity and hypolipidemic effects of ethanolic extract from Alpinia officinarum Hance (Zingiberaceae) in rats fed high-fat diet. J Med Food 13: 785-791.

41 Hwang JT (2012) Decursin, an active compound isolated from Angelica gigas, inhibits fat accumulation, reduces adipocytokine secretion and improves glucose tolerance in mice fed a high-fat diet. Phytother Res 26: 633-638.

2 Kumar S, Alagawadi KR, Rao MR (2011) Effect of Argyreia speciosa root extract on cafeteria diet-induced obesity in rats. Indian J Pharmacol 43: 163-167.

43 Choi Y, Yanagawa Y, Kim S, Whang WK, Park T (2013) Artemisia iwayomogi Extract Attenuates High-Fat Diet-Induced Obesity by Decreasing the Expression of Genes Associated with Adipogenesis in Mice. Evid Based Complement Alternat Med 2013: 915953.

44. Jiao P, Tseng-Crank J, Corneliusen B, Yimam M, Hodges M, et al. (2014) Lipase inhibition and antiobesity effect of Atractylodes lancea. Planta Med 80: 577-582.

45 Lee HM, Yang G, Ahn TG, Kim MD, Nugroho A, et al. (2013) Antiadipogenic Effects of Aster glehni Extract: In Vivo and In Vitro Effects. Evid Based Complement Alternat Med 2013: 859624.

46 Balamurugan G, Muralidharan P (2010) Antiobesity effect of Bauhinia variegata bark extract on female rats fed on hypercaloric diet. Bangladesh Journal of Pharmacology 5: 8-12.

Shikov AN, Pozharitskaya ON, Makarova MN, Makarov VG, Wagner H (2014) Bergenia crassifolia (L.) Fritsch--pharmacology and phytochemistry. Phytomedicine 21: 1534-1542.

48 Lee JJ (2011) Effects of Ramie Leaves on Improvement of Lipid Metabolism and Antiobesity Effect in Rats Fed a High Fat/High Cholesterol Diet. Korean Journal of Food Science and Technology 43: 83-90.

Khalid M, Siddiqui HH (2012) Evaluation of weight reduction and anti-cholesterol activity of Punarnava root extract against high fat diets induced obesity in experimental rodent. Asian Pacific Journal of Tropical Biomedicine 2: S1323-S1328.

50 Gupta P, Goyal R, Chauhan Y, Sharma PL (2013) Possible modulation of FAS and PTP-1B signaling in ameliorative potential of Bombax ceiba against high fat diet induced obesity. BMC Complement Altern Med 13: 281.

Kim H, Choung SY (2012) Anti-obesity effects of Boussingaulti gracilis Miers var. pseudobaselloides Bailey via activation of AMP-activated protein kinase in 3T3-L1 cells. J Med Food 15: 811-817.

An S, Han JI, Kim MJ, Park JS, Han JM, et al. (2010) Ethanolic extracts of Brassica campestris spp. rapa roots prevent high-fat diet-induced obesity via beta(3)-adrenergic regulation of white adipocyte lipolytic activity. J Med Food 13: 406-414.

Roh C, Park MK, Shin HJ, Jung U, Kim JK (2012) Buddleja officinalis Maximowicz extract inhibits lipid accumulation on adipocyte differentiation in 3T3-L1 cells and high-fat mice. Molecules 17: 86878695.

54. Aguilar Santamaría L (2012) Effect of Bursera grandiflora on body weight and lipemia in obese mice. Efecto de Bursera grandiflora sobre el peso corporal y lipemia en ratones obesos 11: 138-146.

Höper AC, Salma W, Sollie SJ, Hafstad AD, Lund J, et al. (2014) Wax esters from the marine copepod Calanus finmarchicus reduce dietinduced obesity and obesity-related metabolic disorders in mice. J Nutr 144: 164-169.
Tamaru S, Ohmachi K, Miyata Y, Tanaka T, Kubayasi T, et al. (2013) Hypotriglyceridemic potential of fermented mixed tea made with third-crop green tea leaves and camellia (Camellia japonica) leaves in Sprague-Dawley rats. J Agric Food Chem 61: 5817-5823.

Chen Q (2014) Polyphenol-rich extracts from Oiltea camellia prevent weight gain in obese mice fed a high-fat diet and slowed the accumulation of triacylglycerols in 3T3-L1 adipocytes. Journal of Functional Foods 9: 148-155.

Abd El-Moneim RA, Abd El-Mouaty HM (2013) A comparative histological, immunohistochemical, and biochemical study of the effect of green tea extracts or chromium picolinate administration on the white visceral adipose tissue and liver in albino rats fed on high-fat diet. The Egyptian Journal of Histology 36: 882-898.

Hamao M, Matsuda H, Nakamura S, Nakashima S, Semura S, et al. (2011) Anti-obesity effects of the methanolic extract and chakasaponins from the flower buds of Camellia sinensis in mice. Bioorg Med Chem 19: 6033-6041.

Kim HJ, Jeon SM, Lee MK, Jung UJ, Shin SK, et al. (2009) Antilipogenic effect of green tea extract in C57BL/6J-Lep ob/ob mice. Phytother Res 23: 467-471.

Lee MS, Kim CT, Kim Y (2009) Green tea (-)-epigallocatechin-3-gallate reduces body weight with regulation of multiple genes expression in adipose tissue of diet-induced obese mice. Ann Nutr Metab 54: 151-157.

62 Li Q, Liu Z, Huang J, Luo G, Liang Q, et al. (2013) Anti-obesity and hypolipidemic effects of Fuzhuan brick tea water extract in high-fat diet-induced obese rats. J Sci Food Agric 93: 1310-1316.

Oi Y, Hou IC, Fujita H, Yazawa K (2012) Antiobesity effects of Chinese black tea (Pu-erh tea) extract and gallic acid. Phytother Res 26: 475-481.

4. Wein S, Schrader E, Rimbach G, Wolffram S (2013) Oral green tea catechins transiently lower plasma glucose concentrations in female $\mathrm{db} / \mathrm{db}$ mice. J Med Food 16: 312-317.

Lamichhane R, Kim SG, Poudel A, Sharma D, Lee KH, et al. (2014) Evaluation of in vitro and in vivo biological activities of Cheilanthes albomarginata Clarke. BMC Complement Altern Med 14: 342.

6 Foucault AS, Mathé V, Lafont R, Even P, Dioh W, et al. (2012) Quinoa extract enriched in 20-hydroxyecdysone protects mice from dietinduced obesity and modulates adipokines expression. Obesity (Silver Spring) 20: 270-277.

67 Inafuku M, Nugara RN, Kamiyama Y, Futenma I, Inafuku A, et al. (2013) Cirsium brevicaule A. GRAY leaf inhibits adipogenesis in 3T3L1 cells and C57BL/6 mice. Lipids Health Dis 12: 124.

58 Lee YS, Cha BY, Saito K, Choi SS, Wang XX, et al. (2011) Effects of a Citrus depressa Hayata (shiikuwasa) extract on obesity in high-fat diet-induced obese mice. Phytomedicine 18: 648-654.

Kang SI, Shin HS, Kim HM, Hong YS, Yoon SA, et al. (2012) Immature Citrus sunki peel extract exhibits antiobesity effects by $\hat{I}^{2}$-oxidation and lipolysis in high-fat diet-induced obese mice. Biol Pharm Bull 35: 223-230.

Chidrawar VR (2012) Pre-clinical evolutionary study of Clerodendrum phlomidis as an anti-obesity agent against high fat diet induced C57BL/6J mice. Asian Pacific Journal of Tropical Biomedicine 2: S1509-S1519.

Ahmed SM, Manoj J (2012) Antiobesity activity of Cocciniaindica in female rats fed with cafeteria and atherogenic diets. Der Pharmacia Lettre 4: 1480-1485. 
2 Choi HK, Won EK, Jang YP, Choung SY (2013) Antiobesity Effect of Codonopsis lanceolata in High-Calorie/High-Fat-Diet-Induced Obese Rats. Evid Based Complement Alternat Med 2013: 210297.

Panchal SK, Poudyal H, Waanders J, Brown L (2012) Coffee extract attenuates changes in cardiovascular and hepatic structure and function without decreasing obesity in high-carbohydrate, high-fat diet-fed male rats. J Nutr 142: 690-697.

Shivaprasad HN, Gopalakrishna S, Mariyanna B, Thekkoot M, Reddy $\mathrm{R}$, et al. (2014) Effect of Coleus forskohlii extract on cafeteria dietinduced obesity in rats. Pharmacognosy Res 6: 42-45.

Shivaprasad HN (2014) Ethnopharmacological and phytomedical knowledge of Coleus forskohlii: An approach towards its safety and therapeutic value. Oriental Pharmacy and Experimental Medicine 14: $301-312$

76 Wang L, Yamasaki M, Katsube T, Sun X, Yamasaki Y, et al. (2011) Antiobesity effect of polyphenolic compounds from molokheiya (Corchorus olitorius L.) leaves in LDL receptor-deficient mice. Eur J Nutr 50: 127-133.

Araldi RP, Rechiutti BM, Mendes TB, Ito ET, Souza EB (2014) Mutagenic potential of Cordia ecalyculata alone and in association with Spirulina maxima for their evaluation as candidate anti-obesity drugs. Genet Mol Res 13: 5207-5220.

Kim HL (2013) Corni Fructus Containing Formulation Attenuates Weight Gain in Mice with Diet-Induced Obesity and Regulates Adipogenesis through AMPK. Evid Based Complement Alternat Med 2013: 423741

Bidkar JS, Ghanwat DD, Bhujbal MD, Dama GY (2012) Antihyperlipidemic activity of Cucumis melo fruit peel extracts in high cholesterol diet induced hyperlipidemia in rats. J Complement Integr Med 9: Article 22

80 Pande S, Srinivasan K (2012) Potentiation of hypolipidemic and weight-reducing influence of dietary tender cluster bean (Cyamopsis tetragonoloba) when combined with capsaicin in high-fat-fed rats. J Agric Food Chem 60: 8155-8162.

Yang DJ, Chang YY, Hsu CL, Liu CW, Lin YL, et al. (2010) Antiobesity and hypolipidemic effects of polyphenol-rich longan (Dimocarpus longans Lour.) flower water extract in hypercaloric-dietary rats. J Agric Food Chem 58: 2020-2027.

Song MY, Lv N, Kim EK, Kwon KS, Yoo YB, et al. (2009) Antiobesity activity of aqueous extracts of Rhizoma Dioscoreae Tokoronis on high-fat diet-induced obesity in mice. J Med Food 12: 304-309.

Hirata T (2014) Chapter 8 - The Chemistry and Bioactivity of Eucommia ulmoides Oliver Leaves, in Studies in Natural Products Chemistry, R. Atta ur, Editor 225-260.

Lee TN (2013) The principle of symmetry in acupuncture and its clinical applications. Am J Chin Med 41: 1223-1231.

Ibarra A, Bai N, He K, Bily A, Cases J, et al. (2011) Fraxinus excelsior seed extract FraxiPureâ,,$\hat{c}$ limits weight gains and hyperglycemia in high-fat diet-induced obese mice. Phytomedicine 18: 479-485.

86 Altiner A (2012) Effect of the antiobesity agent garcinia cambogia extract on serum lipoprotein (a), apolipoproteins a1 and b, and total cholesterol levels in female rats fed atherogenic diet. The Journal of Animal and Plant Sciences 22: 872-877.

Márquez F, Babio N, Bulló M, Salas-Salvadó J (2012) Evaluation of the safety and efficacy of hydroxycitric acid or Garcinia cambogia extracts in humans. Crit Rev Food Sci Nutr 52: 585-594.
Sung YY, Yoon T, Yang WK, Kim SJ, Kim HK (2011) Anti-obesity effects of Geranium thunbergii extract via improvement of lipid metabolism in high-fat diet-induced obese mice. Mol Med Rep 4: 1107-1113.

Kim HJ (2014) The inhibitory effect of saponin derived from Cheonggukjang on adipocyte differentiation In vitro. Food Science and Biotechnology 23: 1273-1278.

Singh BP, Vij S, Hati S (2014) Functional significance of bioactive peptides derived from soybean. Peptides 54: 171-179.

Kumar V, Bhandari U, Tripathi CD, Khanna G (2012) Evaluation of antiobesity and cardioprotective effect of Gymnema sylvestre extract in murine model. Indian J Pharmacol 44: 607-613.

92 Kumar V, Bhandari U, Tripathi CD, Khanna G (2013) Anti-obesity effect of Gymnema sylvestre extract on high fat diet-induced obesity in Wistar rats. Drug Res (Stuttg) 63: 625-632.

Reddy RM, Latha PB, Vijaya T, Rao DS (2012) The saponin-rich fraction of a Gymnema sylvestre $\mathrm{R}$. Br. aqueous leaf extract reduces cafeteria and high-fat diet-induced obesity. Z Naturforsch C 67: 39-46.

Karthik M, Gayathri C (2013) Effect of ethanolic extract of Hibiscus cannabinus leaf on high cholesterol diet induced obesity in female albino rats. Asian Journal of Pharmaceutical and Clinical Research. Asian J Pharm Clin Res 6: 65-67.

Patel S (2014) Hibiscus sabdariffa: An ideal yet under-exploited candidate for nutraceutical applications. Biomedicine \& Preventive Nutrition 4: 23-27.

Villalpando-Arteaga EV, Mendieta-Condado E, Esquivel-Solís $H$, Canales-Aguirre AA, Gálvez-Gastélum FJ, et al. (2013) Hibiscus sabdariffa $L$. aqueous extract attenuates hepatic steatosis through down-regulation of PPAR- $\hat{I}^{3}$ and SREBP-1c in diet-induced obese mice. Food Funct 4: 618-626.

Subash AK, Augustine A (2013) Hypolipidaemic effects of methanol extract of Holoptelea integrifolia (Roxb.) Planchon bark in dietinduced obese rats. Appl Biochem Biotechnol 169: 546-553.

98 Sumiyoshi M, Kimura Y (2013) Hop (Humulus lupulus L.) extract inhibits obesity in mice fed a high-fat diet over the long term. $\mathrm{Br} J$ Nutr 109: 162-172.

Yui K, Kiyofuji A, Osada K (2014) Effects of xanthohumol-rich extract from the hop on fatty acid metabolism in rats fed a high-fat diet. $J$ Oleo Sci 63: 159-168.

100 Adeneye AA, Adeyemi OO, Agbaje EO (2010) Anti-obesity and antihyperlipidaemic effect of Hunteria umbellata seed extract in experimental hyperlipidaemia. J Ethnopharmacol 130: 307-314.

101 García-de la Cruz L, Galvan-Goiz Y, Caballero-Caballero S, Zamudio S, Alfaro A, et al. (2013) Hypericum silenoides Juss. and Hypericum philonotis Cham. \& Schlecht. extracts: in-vivo hypolipidaemic and weight-reducing effects in obese rats. J Pharm Pharmacol 65: 591-603.

102 Arçari DP, Bartchewsky W, dos Santos TW, Oliveira KA, Funck A, et al. (2009) Antiobesity effects of yerba maté extract (Ilex paraguariensis) in high-fat diet-induced obese mice. Obesity (Silver Spring) 17: 2127-2133.

103 Arçari DP, Santos JC, Gambero A, Ribeiro ML (2013) The in vitro and in vivo effects of yerba mate (Ilex paraguariensis) extract on adipogenesis. Food Chem 141: 809-815.

104 Gosmann G, Barlette AG, Dhamer T, Arçari DP, Santos JC, et al. (2012) Phenolic compounds from maté (Ilex paraguariensis) inhibit adipogenesis in 3T3-L1 preadipocytes. Plant Foods Hum Nutr 67: 156-161. 
105 Resende PE, Verza SG, Kaiser S, Gomes LF, Kucharski LC, et al. (2012) The activity of mate saponins (Ilex paraguariensis) in intraabdominal and epididymal fat, and glucose oxidation in male Wistar rats. J Ethnopharmacol 144: 735-740.

106 Ju JH, Yoon HS, Park HJ, Kim MY, Shin HK, et al. (2011) Anti-obesity and antioxidative effects of purple sweet potato extract in 3T3-L1 adipocytes in vitro. J Med Food 14: 1097-1106.

107 Jang WS, Choung SY (2013) Antiobesity Effects of the Ethanol Extract of Laminaria japonica Areshoung in High-Fat-Diet-Induced Obese Rat. Evid Based Complement Alternat Med 2013: 492807.

108 Oh J (2015) The herbal composition GGEx18 from Laminaria japonica, Rheum palmatum, and Ephedra sinica inhibits visceral obesity and insulin resistance by upregulating visceral adipose genes involved in fatty acid oxidation. Pharm Biol 53: 301-312.

109 Harbilas D (2012) Larix laricina, an Antidiabetic Alternative Treatment from the Cree of Northern Quebec Pharmacopoeia, Decreases Glycemia and Improves Insulin Sensitivity In Vivo. Evid Based Complement Alternat Med 2012: 296432.

110 Cha KH (2012) Inhibition of gastrointestinal lipolysis by green tea, coffee, and gomchui (Ligularia fischeri) tea polyphenols during simulated digestion. J Agric Food Chem 60: 7152-7157.

111 Liu Q, Kim SH, Kim SB, Jo YH, Kim ES, et al. (2014) Anti-obesity effect of (8-E)-niizhenide, a secoiridoid from Ligustrum lucidum, in highfat diet-induced obese mice. Nat Prod Commun 9: 1399-1401.

112 Zhou CJ, Huang S, Liu JQ, Qiu SQ, Xie FY, et al. (2013) Sweet tea leaves extract improves leptin resistance in diet-induced obese rats. J Ethnopharmacol 145: 386-392.

113 Gwon SY (2012) Lithospermum erythrorhizon suppresses highfat diet-induced obesity, and acetylshikonin, a main compound of Lithospermum erythrorhizon, inhibits adipocyte differentiation. J Agric Food Chem 60: 9089-9096.

Ko BS (2013) Prunus mume and Lithospermum erythrorhizon Extracts Synergistically Prevent Visceral Adiposity by Improving Energy Metabolism through Potentiating Hypothalamic Leptin and Insulin Signalling in Ovariectomized Rats. Evid Based Complement Alternat Med 2013: 750986.

115 Saminathan M (2013) Systematic review on anticancer potential and other health beneficial pharmacological activities of novel medicinal plant Morinda citrifolia (Noni). . Int J Pharmacol 9: 462-492.

116 Yang Y, Yang X, Xu B, Zeng G, Tan J, et al. (2014) Chemical constituents of Morus alba L. and their inhibitory effect on 3T3-L1 preadipocyte proliferation and differentiation. Fitoterapia 98: 222-227.

117 Wu T, Qi X, Liu Y, Guo J, Zhu R, et al. (2013) Dietary supplementation with purified mulberry (Morus australis Poir) anthocyanins suppresses body weight gain in high-fat diet fed C57BL/6 mice. Food Chem 141: 482-487.

118 Lim HH, Lee SO, Kim SY, Yang SJ, Lim Y (2013) Anti-inflammatory and antiobesity effects of mulberry leaf and fruit extract on high fat dietinduced obesity. Exp Biol Med (Maywood) 238: 1160-1169.

119 Na HN, Park S, Jeon HJ, Kim HB, Nam JH (2014) Reduction of adenovirus 36-induced obesity and inflammation by mulberry extract. Microbiol Immunol 58: 303-306.

120 Peng CH, Liu LK, Chuang CM, Chyau CC, Huang CN, et al. (2011) Mulberry water extracts possess an anti-obesity effect and ability to inhibit hepatic lipogenesis and promote lipolysis. J Agric Food Chem 59: 2663-2671.
Birari R, Javia V, Bhutani KK (2010) Antiobesity and lipid lowering effects of Murraya koenigii (L.) Spreng leaves extracts and mahanimbine on high fat diet induced obese rats. Fitoterapia 81: 1129-1133.

122 Nascimento OV, Boleti AP, Yuyama LK, Lima ES (2013) Effects of diet supplementation with Camu-camu (Myrciaria dubia HBK McVaugh) fruit in a rat model of diet-induced obesity. An Acad Bras Cienc 85: 355-363.

123 Ahmed AH (2013) Flavonoid Content and Antiobesity Activity of Leaves of Myrtus communis. Asian Journal of Chemistry 25: 68186826.

124 Ahn JH, Kim ES, Lee C, Kim S, Cho SH, et al. (2013) Chemical constituents from Nelumbo nucifera leaves and their anti-obesity effects. Bioorg Med Chem Lett 23: 3604-3608.

25 Du H (2010) Antiobesity and hypolipidemic effects of lotus leaf hot water extract with taurine supplementation in rats fed a high fat diet. J Biomed Sci 17: S42.

126 Velusami CC, Agarwal A, Mookambeswaran V (2013) Effect of Nelumbo nucifera Petal Extracts on Lipase, Adipogenesis, Adipolysis, and Central Receptors of Obesity. Evid Based Complement Alternat Med 2013: 145925.

7 You JS, Lee YJ, Kim KS, Kim SH, Chang KJ (2014) Anti-obesity and hypolipidaemic effects of Nelumbo nucifera seed ethanol extract in human pre-adipocytes and rats fed a high-fat diet. J Sci Food Agric 94: 568-575.

28 Zhao YX, Liang WJ, Fan HJ, Ma QY, Tian WX, et al. (2011) Fatty acid synthase inhibitors from the hulls of Nephelium lappaceum L. Carbohydr Res 346: 1302-1306.

29 Zar Kalai F, Han J, Ksouri R, Abdelly C, Isoda H (2014) Oral administration of Nitraria retusa ethanolic extract enhances hepatic lipid metabolism in $\mathrm{db} / \mathrm{db}$ mice model 'BKS.Cg-Dock7(m)+/+ Lepr(db/)J' through the modulation of lipogenesis-lipolysis balance. Food Chem Toxicol 72: 247-256.

30 Poudyal H, Campbell F, Brown L (2010) Olive leaf extract attenuates cardiac, hepatic, and metabolic changes in high carbohydrate-, high fat-fed rats. J Nutr 140: 946-953.

31 Vogel P, Kasper Machado I, Garavaglia J, Zani VT, de Souza D, et al. (2014) Polyphenols benefits of olive leaf (Olea europaea L) to human health. Nutr Hosp 31: 1427-1433.

32 Choi YJ, Park SY, Kim JY, Won KC, Kim BR, et al. (2013) Combined treatment of betulinic acid, a PTP1B inhibitor, with Orthosiphon stamineus extract decreases body weight in high-fat-fed mice. J Med Food 16: 2-8.

33 Lim S, Yoon JW, Choi SH, Cho BJ, Kim JT, et al. (2009) Effect of ginsam, a vinegar extract from Panax ginseng, on body weight and glucose homeostasis in an obese insulin-resistant rat model. Metabolism 58: 8-15.

134 Park J, Jeon YD, Kim HL, Lim H, Jung Y, et al. (2013) Interaction of Veratrum nigrum with Panax ginseng against Obesity: A Sang-ban Relationship. Evid Based Complement Alternat Med 2013: 732126.

Kim MJ, Kim HK (2009) Perilla leaf extract ameliorates obesity and dyslipidemia induced by high-fat diet. Phytother Res 23: 1685-1690.

36 Watanabe T, Hata K, Hiwatashi K, Hori K, Suzuki N, et al. (2010) Suppression of murine preadipocyte differentiation and reduction of visceral fat accumulation by a Petasites japonicus ethanol extract in mice fed a high-fat diet. Biosci Biotechnol Biochem 74: 499-503. 
137 Carai MA, Fantini N, Loi B, Colombo G, Gessa GL, et al. (2011) Multiple cycles of repeated treatments with a Phaseolus vulgaris dry extract reduce food intake and body weight in obese rats. $\mathrm{Br} J$ Nutr 106: 762-768.

138 Higa JK, Liu W, Berry MJ, Panee J (2011) Supplement of bamboo extract lowers serum monocyte chemoattractant protein-1 concentration in mice fed a diet containing a high level of saturated fat. Br J Nutr 106: 1810-1813.

139 Ko HS (2013) Essential Oil of Pinus koraiensis Exerts Antiobesic and Hypolipidemic Activity via Inhibition of Peroxisome ProliferatorActivated Receptors Gamma Signaling. Evid Based Complement Alternat Med 2013: 947037.

140 Darusman LK, Batubara II (2014) U.M. R., Fractionation of active components from Piper cf. fragile essential oil as aromatherapy for anti-obesity. Acta Horticulturae 1023: 23-28.

141 Suhana Mohd Ramli E, Nirwana Soelaiman I, Othman F, Ahmad F, Nazrun Shuib A, et al. (2012) The effects of piper sarmentosum water extract on the expression and activity of $11 \beta$-hydroxysteroid dehydrogenase type 1 in the bones with excessive glucocorticoids. Iran J Med Sci 37: 39-46.

142 Zhao HL, Harding SV, Marinangeli CP, Kim YS, Jones PJ (2008) Hypocholesterolemic and anti-obesity effects of saponins from Platycodon grandiflorum in hamsters fed atherogenic diets. J Food Sci 73: H195-200.

143 Sung YY, Yoon T, Yang WK, Kim SJ, Kim DS, et al. (2013) The Antiobesity Effect of Polygonum aviculare L. Ethanol Extract in HighFat Diet-Induced Obese Mice. Evid Based Complement Alternat Med 2013: 626397.

144. Harbilas D (2013) Populus balsamifera Extract and Its Active Component Salicortin Reduce Obesity and Attenuate Insulin Resistance in a Diet-Induced Obese Mouse Model. Evid Based Complement Alternat Med 2013: 172537.

145 Mali PY, Bigoniya P, Panchal SS, Muchhandi IS (2013) Anti-obesity activity of chloroform-methanol extract of Premna integrifolia in mice fed with cafeteria diet. J Pharm Bioallied Sci 5: 229-236.

146 Kamiya T, Sameshima-Kamiya M, Nagamine R, Tsubata M, Ikeguchi $M$, et al. (2012) The crude extract from puerariae flower exerts antiobesity and antifatty liver effects in high-fat diet-induced obese mice. Evid Based Complement Alternat Med 2012: 272710.

147 Adnyana IK (2014) Anti-obesity effect of the pomegranate leaves ethanol extract (Punica granatuml.) in high-fat diet induced mice. International Journal of Pharmacy and Pharmaceutical Sciences 6: 626-631.

148 Viladomiu M, Hontecillas R, Lu P, Bassaganya-Riera J (2013) Preventive and prophylactic mechanisms of action of pomegranate bioactive constituents. Evid Based Complement Alternat Med 2013: 789764.

149 Shin SS, Park D, Lee HY, Hong Y, Choi J, et al. (2012) The herbal composition GGEx18 from Laminaria japonica, Rheum palmatum, and Ephedra sinica reduces obesity via skeletal muscle AMPK and PPAR $\alpha$. Pharm Biol 50: 506-515.

150 Zhang Y, Fan S, Hu N, Gu M, Chu C, et al. (2012) Rhein Reduces Fat Weight in $\mathrm{db} / \mathrm{db}$ Mouse and Prevents Diet-Induced Obesity in C57BI/6 Mouse through the Inhibition of PPARy Signaling. PPAR Res 2012: 374936.

151 Romo Vaquero M, Yáñez-Gascón MJ, García Villalba R, Larrosa M, Fromentin E, et al. (2012) Inhibition of gastric lipase as a mechanism for body weight and plasma lipids reduction in Zucker rats fed a rosemary extract rich in carnosic acid. PLoS One 7: e39773.

52 Kaume L, Howard LR, Devareddy L (2012) The blackberry fruit: a review on its composition and chemistry, metabolism and bioavailability, and health benefits. J Agric Food Chem 60: 57165727.

153 Suneetha DS, Divya TB, Ali F (2013) Antiobesity values of methanolic extract of Sapindus emariganatus on monosodium glutamate induced model in rats. . International Journal of Pharmacognosy and Phytochemical Research 5: 267-270.

154 Kang SI, Shin HS, Kim HM, Hong YS, Yoon SA, et al. (2012) Antiobesity properties of a Sasa quelpaertensis extract in high-fat dietinduced obese mice. Biosci Biotechnol Biochem 76: 755-761.

55 Kang SW, Kang SI, Shin HS, Yoon SA, Kim JH, et al. (2013) Sasa quelpaertensis Nakai extract and its constituent p-coumaric acid inhibit adipogenesis in 3T3-L1 cells through activation of the AMPK pathway. Food Chem Toxicol 59: 380-385.

56 Park HJ (2012) Anti-obesity effect of Schisandra chinensis in 3T3-L1 cells and high fat diet-induced obese rats. Food Chemistry 134: 227-234.

57 Kumar D, Karmase A, Jagtap S, Shekhar R, Bhutani KK (2013) Pancreatic lipase inhibitory activity of cassiamin A, a bianthraquinone from Cassia siamea. Nat Prod Commun 8: 195-198.

158 Supriya KSK, Vrushabendra Swamy BM, Archana Swamy $P$, Vishwanath KM1 Anti-Obesity Activity of Shorea robusta G. Leaves Extract on Monosodium Glutamate Induced Obesity in Albino Rats. Research Journal of Pharmaceutical, Biological and Chemical Sciences.

59 Thounaojam MC, Jadeja RN, Ramani UV, Devkar RV, Ramachandran AV (2011) Sida rhomboidea. Roxb leaf extract down-regulates expression of PPARY2 and leptin genes in high fat diet fed C57BL/6J Mice and retards in vitro 3T3L1 pre-adipocyte differentiation. Int J Mol Sci 12: 4661-4677.

60 Choi KM, Lee YS, Shin DM, Lee S, Yoo KS, et al. (2013) Green tomato extract attenuates high-fat-diet-induced obesity through activation of the AMPK pathway in C57BL/6 mice. J Nutr Biochem 24: 335-342.

161 Perveen R (2015) Tomato (Solanum lycopersicum) Carotenoids and Lycopenes Chemistry; Metabolism, Absorption, Nutrition, and Allied Health Claims-A Comprehensive Review. Crit Rev Food Sci Nutr 55: 919-929.

162 Jung CH, Ahn J, Jeon TI, Kim TW, Ha TY (2012) Syzygium aromaticum ethanol extract reduces high-fat diet-induced obesity in mice through downregulation of adipogenic and lipogenic gene expression. Exp Ther Med 4: 409-414.

63 Azman KF, Amom Z, Azlan A, Esa NM, Ali RM, et al. (2012) Antiobesity effect of Tamarindus indica L. pulp aqueous extract in high-fat dietinduced obese rats. J Nat Med 66: 333-342.

164 Jindal V, Dhingra D, Sharma S, Parle M, Harna RK (2011) Hypolipidemic and weight reducing activity of the ethanolic extract of Tamarindus indica fruit pulp in cafeteria diet- and sulpiride-induced obese rats. $J$ Pharmacol Pharmacother 2: 80-84.

165 Sasidharan SR, Joseph JA, Anandakumar S, Venkatesan V, Madhavan $\mathrm{CN}$, et al. (2014) Ameliorative potential of Tamarindus indica on high fat diet induced nonalcoholic fatty liver disease in rats. ScientificWorldJournal 2014: 507197.

166 Alvala R, Alvala M, Sama V, Dharmarajan S, Ullas JV, et al. (2013) Scientific evidence for traditional claim of anti-obesity activity of 
Tecomella undulata bark. J Ethnopharmacol 148: 441-448.

167 Song Y, Park HJ, Kang SN, Jang SH, Lee SJ, et al. (2013) Blueberry peel extracts inhibit adipogenesis in 3T3-L1 cells and reduce high-fat diet-induced obesity. PLoS One 8: e69925.

168 Kitano-Okada T, Ito A, Koide A, Nakamura Y, Han KH, et al. (2012) Anti-obesity role of adzuki bean extract containing polyphenols: in vivo and in vitro effects. J Sci Food Agric 92: 2644-2651.

169 Son Y, Nam JS, Jang MK, Jung IA, Cho SI, et al. (2013) Antiobesity activity of Vigna nakashimae extract in high-fat diet-induced obesity. Biosci Biotechnol Biochem 77: 332-338.

170 Jung HY, Kim YH, Kim IB, Jeong JS, Lee JH, et al. (2013) The Korean Mistletoe (Viscum album coloratum) Extract Has an Antiobesity Effect and Protects against Hepatic Steatosis in Mice with High-Fat Diet-Induced Obesity. Evid Based Complement Alternat Med 2013: 168207.

171 Hsu HM (2014) Vitis thunbergii supplementation demonstrates an anti-obesity effect in developing obese mice. European Journal of Integrative Medicine 6: 581-587.

172 Kim YM, Lee EW, Eom SH, Kim TH (2014) Pancreatic lipase inhibitory stilbenoids from the roots of Vitis vinifera. Int J Food Sci Nutr 65: 97-100.

173 Jeong YS (2012) Grape skin extract reduces adipogenesis- and lipogenesis-related gene expression in 3T3-L1 adipocytes through the peroxisome proliferator-activated receptor-gamma signaling pathway. Nutr Res 32: 514-521.

174 Jeong YS (2011) Anti-obesity effect of grape skin extract in 3T3-L1 adipocytes. Food Sci and Biotechnology 20: 635-642.

175 Kang JS, Lee WK, Lee CW, Yoon WK, Kim N, et al. (2011) Improvement of high-fat diet-induced obesity by a mixture of red grape extract, soy isoflavone and L-carnitine: implications in cardiovascular and non-alcoholic fatty liver diseases. Food Chem Toxicol 49: 2453-2458.

176 Kim H (2014) Dietary supplementation of chardonnay grape seed flour reduces plasma cholesterol concentration, hepatic steatosis, and abdominal fat content in high-fat diet-induced obese hamsters. J Agric Food Chem 62: 1919-1925.

Oh J (2013) Antioxidant and antiobesity activities of seed extract from campbell early grape as a functional ingredient. Journal of Food Processing and Preservation 37: 291-298.

178 Zhang XH, Huang B, Choi SK, Seo JS (2012) Anti-obesity effect of resveratrol-amplified grape skin extracts on 3T3-L1 adipocytes differentiation. Nutr Res Pract 6: 286-293.

179 Gwon SY, Ahn JY, Kim TW, Ha TY (2012) Zanthoxylum piperitum DC ethanol extract suppresses fat accumulation in adipocytes and high fat diet-induced obese mice by regulating adipogenesis. J Nutr Sci Vitaminol (Tokyo) 58: 393-401.

180 Deshpande MS (2013) Anti-obesity activity of Ziziphus mauritiana: A potent pancreatic lipase inhibitor. Asian Journal of Pharmaceutical and Clinical Research 6: 168-173.

181 Sung YY, Kim DS, Choi G, Kim SH, Kim HK (2014) Dohaekseunggi-tang extract inhibits obesity, hyperlipidemia, and hypertension in highfat diet-induced obese mice. BMC Complement Altern Med 14: 372.

182 Ahn EK, Lee JA, Seo DW, Hong SS, Oh JS (2012) 13-Hydroxy-2oxopomolic acid isolated from Agrimonia pilosa extract inhibits adipogenesis in 3T3-L1 cells. Biol Pharm Bull 35: 643-649.

183 Lee M, Song JY, Chin YW, Sung SH (2013) Anti-adipogenic diarylheptanoids from Alnus hirsuta f. sibirica on 3T3-L1 cells. Bioorg Med Chem Lett 23: 2069-2073.

84 Park JA (2014) Anti-oxidative and anti-obesity effects of Amomum cardamomum L. Extract. Korean Journal of Microbiology and Biotechnology 42: 249-257.

85 Bansal V (2014) Phytochemical, Pharmacological Profile and Commercial Utility of Tropically Distributed Plant Bauhinia variegata. Global Journal of Pharmacology 8: 196-205.

186 Liang CH (2013) Brazilein from Caesalpinia sappan L. Antioxidant Inhibits Adipocyte Differentiation and Induces Apoptosis through Caspase-3 Activity and Anthelmintic Activities against Hymenolepis nana and Anisakis simplex. Evid Based Complement Alternat Med 2013: 864892.

187 Kim GS, Park HJ, Woo JH, Kim MK, Koh PO, et al. (2012) Citrus aurantium flavonoids inhibit adipogenesis through the Akt signaling pathway in 3T3-L1 cells. BMC Complement Altern Med 12: 31.

188 Stohs SJ, Preuss HG, Shara M (2012) A review of the human clinical studies involving Citrus aurantium (bitter orange) extract and its primary protoalkaloid p-synephrine. Int J Med Sci 9: 527-538.

89 Choi JS, Kim JH, Ali MY, Min BS, Kim GD, et al. (2014) Coptis chinensis alkaloids exert anti-adipogenic activity on 3T3-L1 adipocytes by downregulating C/EBP- $\alpha$ and PPAR- - . Fitoterapia 98: 199-208.

190 Lee J, Kim D, Choi J, Choi H, Ryu JH, et al. (2012) Dehydrodiconiferyl alcohol isolated from Cucurbita moschata shows anti-adipogenic and anti-lipogenic effects in 3T3-L1 cells and primary mouse embryonic fibroblasts. J Biol Chem 287: 8839-8851.

191 Bradford PG (2013) Curcumin and obesity. Biofactors 39: 78-87.

192 Ho JN (2013) Standardized Ethanol Extract of Curcuma longa L. Fermented by Aspergillus oryzae Promotes Lipolysis via Activation of cAMP-Dependent PKA in 3T3-L1 Adipocytes. Journal of Food Biochemistry 37: 595-603.

193 Dudhia Z, Louw J, Muller C, Joubert E, de Beer D, et al. (2013) Cyclopia maculata and Cyclopia subternata (honeybush tea) inhibits adipogenesis in 3T3-L1 pre-adipocytes. Phytomedicine 20: 401-408.

194 G RJN (2012) A Study on Ethanolic Extract of Dalbergia sissoo roxb. Leaves for Pancreatic Lipase Inhibition. Journal of Pharmacy and Technology 5: 497-500.

95 Yang MH, Chin YW, Chae HS, Yoon KD, Kim J (2014) Anti-adipogenic constituents from Dioscorea opposita in 3T3-L1 cells. Biol Pharm Bull 37: 1683-1688.

196 Park HJ, Chung BY, Lee MK, Song Y, Lee SS, et al. (2012) Centipede grass exerts anti-adipogenic activity through inhibition of $C / E B P \beta$, C/EBP $\alpha$, and PPAR $y$ expression and the AKT signaling pathway in 3T3-L1 adipocytes. BMC Complement Altern Med 12: 230.

197 Kang H, Koppula S (2014) Houttuynia cordata attenuates lipid accumulation via activation of AMP-activated protein kinase signaling pathway in HepG2 cells. Am J Chin Med 42: 651-664.

198 Miyata M, Koyama T, Yazawa K (2010) Water extract of Houttuynia cordata Thunb. leaves exerts anti-obesity effects by inhibiting fatty acid and glycerol absorption. J Nutr Sci Vitaminol (Tokyo) 56: 150-156.

99 Ngondi JL (2009) IGOB131, a novel seed extract of the West African plant Irvingia gabonensis, significantly reduces body weight and improves metabolic parameters in overweight humans in a randomized double-blind placebo controlled investigation. Lipids Health Dis 8: 7. 
200 Kim YS, Lee YM, Kim H, Kim J, Jang DS, et al. (2010) Anti-obesity effect of Morus bombycis root extract: anti-lipase activity and lipolytic effect. J Ethnopharmacol 130: 621-624.

201 Roh C, Jung U (2012) Nepeta japonica Maximowicz extract from natural products inhibits lipid accumulation. J Sci Food Agric 92: 2195-2199.

202 Kim HR, Kim JM, Kim MS, Hwang JK, Yang SH, et al. (2014) Inhibitory effects of Pericarpium zanthoxyli extract on adipocyte differentiation. Int J Mol Med 33: 1140-1146.

203 Nugara RN, Inafuku M, Iwasaki H, Oku H (2014) Partially purified Peucedanum japonicum Thunb extracts exert anti-obesity effects in vitro. Nutrition 30: 575-583.

204 Nugara RN, Inafuku M, Takara K, Iwasaki H, Oku H (2014) Pteryxin: a coumarin in Peucedanum japonicum Thunb leaves exerts antiobesity activity through modulation of adipogenic gene network. Nutrition 30: 1177-1184.

205 Ezure T, Amano S (2011) Rubus suavissimus S. Lee extract increases early adipogenesis in 3T3-L1 preadipocytes. J Nat Med 65: 247-253.

206 Kong CS, Seo Y (2012) Antiadipogenic activity of isohamnetin 3-O- $\hat{I}^{2}$ D-glucopyranoside from Salicornia herbacea. Immunopharmacol Immunotoxicol 34: 907-911.

207 Park JA (2013) Anti-oxidative and anti-obesity activities of Tetrapanax papyriferus and Siegesbeckia pubescens extracts and their synergistic anti-obesity effects. Korean Journal of Microbiology and Biotechnology 41: 341-349.

208 Kang YH (2013) Study on antioxidative, antidiabetic and antiobesity activity of solvent fractions of smilax china L. leaf extract. Journal of Nutrition and Health 46: 401-409.

209 Gao QH, Wu CS, Wang M (2013) The jujube (Ziziphus jujuba Mill.) fruit: a review of current knowledge of fruit composition and health benefits. J Agric Food Chem 61: 3351-3363.

210 Mostafa UE, Labban L (2013) The Effect of Zizyphus jujube on Serum Lipid Profile and Some Anthropometric Measurements. Pakistan Journal of Nutrition 12: 538-543.

11 Kubota H, Morii R, Kojima-Yuasa A, Huang X, Yano Y, et al. (2009) Effect of Zizyphus jujuba extract on the inhibition of adipogenesis in 3T3-L1 preadipocytes. Am J Chin Med 37: 597-608.

12 Ho JN, Son ME, Lim WC, Lim ST, Cho HY (2012) Anti-obesity effects of germinated brown rice extract through down-regulation of lipogenic genes in high fat diet-induced obese mice. Biosci Biotechnol Biochem 76: 1068-1074

Kazemipoor M, Radzi CW, Hajifaraji M, Haerian BS, Mosaddegh MH, et al. (2013) Antiobesity effect of caraway extract on overweight and obese women: a randomized, triple-blind, placebo-controlled clinical trial. Evid Based Complement Alternat Med 2013: 928582.
4. Oben J, Kuate D, Agbor G, Momo C, Talla X (2006) The use of a Cissus quadrangularis formulation in the management of weight loss and metabolic syndrome. Lipids Health Dis 5: 24.

215 Park SH, Huh TL, Kim SY, Oh MR, Tirupathi Pichiah PB, et al. (2014) Antiobesity effect of Gynostemma pentaphyllum extract (actiponin): a randomized, double-blind, placebo-controlled trial. Obesity (Silver Spring) 22: 63-71.

216 Najmi A, Nasiruddin M, Khan RA, Haque SF (2008) Effect of Nigella sativa oil on various clinical and biochemical parameters of insulin resistance syndrome. Int J Diabetes Dev Ctries 28: 11-14.

217 Razavi BM, Hosseinzadeh $\mathrm{H}$ (2014) A review of the effects of Nigella sativa L. and its constituent, thymoquinone, in metabolic syndrome. J Endocrinol Invest 37: 1031-1040.

218 Ofner M, Tomaschitz A, Wonisch M, Litscher G (2013) Complementary treatment of obesity and overweight with salacia reticulata and vitamin d. Int J Vitam Nutr Res 83: 216-223.

219 Chevassus H, Gaillard JB, Farret A, Costa F, Gabillaud I, et al. (2010) A fenugreek seed extract selectively reduces spontaneous fat intake in overweight subjects. Eur J Clin Pharmacol 66: 449-455.

220 Szewczyk K, Zidorn C (2014) Ethnobotany, phytochemistry, and bioactivity of the genus Turnera (Passifloraceae) with a focus on damiana--Turnera diffusa. J Ethnopharmacol 152: 424-443.

221 Andersen T, Fogh J (2001) Weight loss and delayed gastric emptying following a South American herbal preparation in overweight patients. J Hum Nutr Diet 14: 243-250.

222 Anastasia UU (2010) Anti-Carcinoma, Anti-Obesity, Antidiabetic and Immune Defence Effects of Vernonia amygdalina Leaf Extract and Leaf Powder, in Two Human Cancer Patients. American Journal of Immunology 6: 50-53.

Dalla Via L, García-Argáez AN, Braga A, Martínez-Vázquez M, Grancara S, et al. (2014) An eudesman derivative from Verbesina persicifolia D.C. as a natural mild uncoupler in liver mitochondria. A new potential anti-obesity agent? Curr Pharm Des 20: 253-261.

224 Ahn JH, Shin E, Liu Q, Kim SB, Choi KM, et al. (2013) Secoiridoids from the stem barks of Fraxinus rhynchophylla with pancreatic lipase inhibitory activity. Nat Prod Res 27: 1132-1135.

25 Gurudeeban S (2012) An in silico approach of alpha-ketoglutarate dependent dioxygenase FTO inhibitors derived from Rhizophora mucronata. Drug Invention Today 4: 594-598.

226 Romo Vaquero M (2014) A rosemary extract enriched in carnosic acid improves circulating adipocytokines and modulates key metabolic sensors in lean Zucker rats: Critical and contrasting differences in the obese genotype. Mol Nutr Food Res 58: 942-953.

7 Qi S, Zhou D (2013) Lotus seed epicarp extract as potential antioxidant and anti-obesity additive in Chinese Cantonese Sausage. Meat Sci 93: 257-262. 